\title{
Metal Heterodiene Complexes
}

\author{
K. VRIF,ZF, and G. VAN KOTEN \\ Anorganisch Chemisch Laboratorium, J. H. van 't Hoff Instituut, Universiteit van Amsterdam, Nieuwe Achtergracht 166, \\ 1018 WV Amsterdam, The Netherlands
}

Received November 20, 1984

\begin{abstract}
In this article a survey is given of novel results in the field of the chemistry of $\alpha$-diimine complexes of some metal atoms of the main group, transition metal and post transition metal area. It is shown that $\alpha$-diimines of the type $R N=C\left(R^{\prime}\right)\left(R^{\prime \prime}\right) C=N R$ $(=\mathrm{R}-\mathrm{DAB})$ and $2-\mathrm{C}_{5} \mathrm{H}_{4} \mathrm{NC}\left(\mathrm{R}^{\prime}\right)=\mathrm{NR}(=\mathrm{R}-\mathrm{Pyca})$ are very versatile with regards to both their coordination chemistry and chemical reactivity when coordinated to a metal or metal cluster. The type of reaction occurring depends critically on the type of metal(s), the other ligands present on the metal(s), the type of coordination of the $\alpha$-diimines, and particularly on the steric and electronic properties of $R, R^{\prime}$ and $\mathrm{R}^{\prime \prime}$ situated on the R-DAB and R-Pyca ligands.
\end{abstract}

\section{Introduction}

Molecules with $\mathrm{C}=\mathrm{N}$ double bonds and in particular the $\alpha$-diimines, 1,4-diaza-1,3-butadienes* and 2-pyridinecarbaldehydeimines* have attracted much interest for their use as ligands in metal complexes. Reasons are (i) the versatile coordination behaviour, due to the good $\sigma$-donor and $\pi$-acceptor characteristics and the flexibility of the $\alpha$-diimine molecule, and (ii), the apparently facile activation of the metal coordinated $\alpha$-diimine for a whole range of both stoichiometric and catalytic reactions [1-13].

In this survey we emphasize the research carried out in our own laboratory, but we recognize the elegant work of other workers in the field [3-13]. Furthermore, we devote attention to new developments in our research and discuss these in the light of highlights of our less recent work.

An outline is given of some relevant properties of the $\alpha$-diimines involved and of the coordination modes which have been observed so far. A more detailed discussion of the subject of $\alpha$-diimines

*1,4-Diaza-1,3-butadienes of the general formula $\mathrm{RN}=\mathrm{C}$ $\left(R^{\prime}\right)\left(R^{\prime \prime}\right) C=N R$ are abbreviated to $R-D A B\left\{R^{\prime} ; R^{\prime \prime}\right\}[1,2]$. $[R N=C(H)(H) C=N R$ will be shortened to $R-D A B$ instead of R-DAB $\{\mathrm{H} ; \mathrm{H}\}$. The pyridineimine formulae will be abbreviated to R-Pyca, which stands for $2-\mathrm{C}_{5} \mathrm{H}_{4} \mathrm{NC}(\mathrm{H})=\mathrm{NR}$. and their metal complexes can be found in several recent reviews $[1,2]$.

The structure of $\mathrm{c}-\mathrm{Hex}-\mathrm{N}=\mathrm{CHHC}=\mathrm{N}-\mathrm{c}-\mathrm{Hex}$ (cHex-DAB) has been determined crystallographically [14], and it was shown that the molecule contains a flat $\mathrm{N}=\mathrm{C}-\mathrm{C}=\mathrm{N}$ skeleton in the E-s-trans-E conformation (sec Fig. 1) with $\mathrm{C}=\mathrm{N}$ and $\mathrm{C}-\mathrm{C}$ bond lengths of $1.2576(22)$ and $1.4571(23) \AA$. The R-Pyca ligands have been less well investigated but a similar conformation in the solid state appears likely (Fig. 1). Important for the understanding of the coordination properties of $\alpha$-diimines to metals is the fact that available evidence indicates that their $\pi$-acceptor capacity increases in the order $2,2^{\prime}$-bipyridine $<2$-pyridinecarbaldehyde- $\mathrm{N}$-methylimine $<$ R-DAB [11].

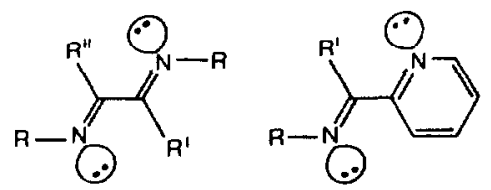

Fig. 1. The ground state conformation of R-DAB and R-Pyca.

Various coordination modes have now been demonstrated, and they are shown in Fig. 2.

Tew complexes containing monodentate R-DAB have been reported. An example where the crystal structure has been determined is trans $-\mathrm{PdCl}_{2}\left(\mathrm{PPh}_{3}\right)(\mathrm{t}$ Bu-DAB) [14]. The $\mathrm{C}=\mathrm{N}$ distances of the coordinated $(\sigma-\mathrm{N}=\mathrm{C})$ and non-coordinated moieties are $1.264(10) \AA$ and $1.239(10) \AA$, respectively. The central $\mathrm{C}-\mathrm{C}$ distance is $1.485(9) \AA$, indicating that the electronic distribution in the $\mathrm{N}=\mathrm{C}-\mathrm{C}=\mathrm{N}$ skeleton of the monodentate bonded t-Bu-DAB, which is still in the flat E-s-trans-E conformation, is scarcely perturbed by metal coordination.

Similarly, a crystal structure determination of [trans- $\left.-\mathrm{PtCl}_{2}\left(\mathrm{PBu}_{3}\right)\right]_{2}(\mathrm{t}-\mathrm{Bu}-\mathrm{DAB})$ showed also little perturbance when both $\mathrm{N}=\mathrm{C}$ groups are $\sigma \cdot \mathrm{N}$ coordinated to a $\mathrm{Pt}$ atom. The $\mathrm{N}=\mathrm{C}$ and $\mathrm{C}-\mathrm{C}$ distances of the flat $\mathrm{N}=\mathrm{C}-\mathrm{C}=\mathrm{N}$ skeleton are 1.27(3) and $1.48(2) \AA$, respectively, while again the R-DAB is present in the E-s-trans-E conformation [15]. 


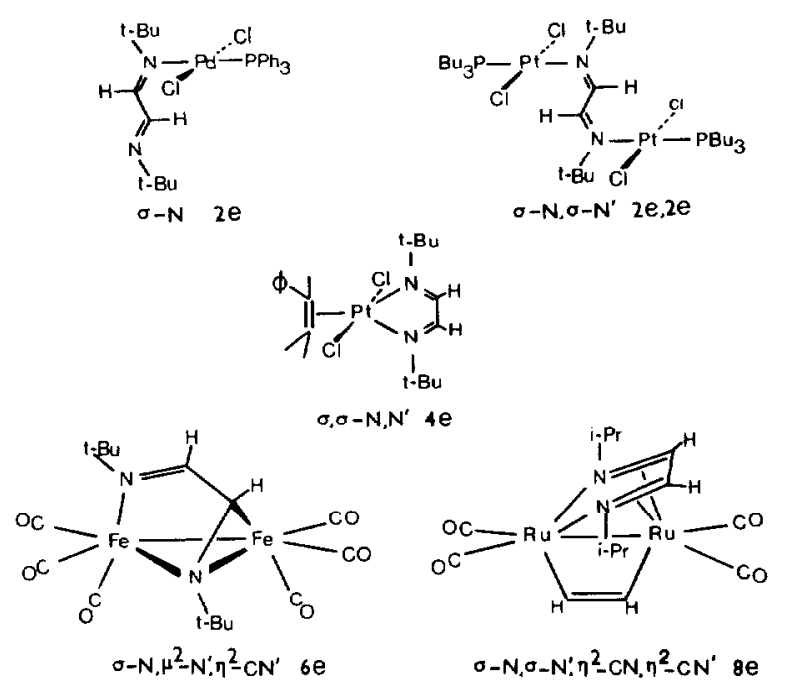

Fig. 2. Examples of R-DAB complexes of which crystal structures are known and which illustrate the most relevant coordination possibilities.

Not only in the case of the chelating $4 \mathrm{e}$ coordination mode of R.DAB, but also for the $6 \mathrm{e}$ - and $8 \mathrm{e}-$ coordination types both $\mathrm{N}$ atoms are $\sigma-\mathrm{N}$ coordinated to one metal atom with the generally flat $\mathrm{N}=\mathrm{C}-\mathrm{C}=\mathrm{N}$ skeleton now in the E-s-cis-E conformation. For the $6 \mathrm{e}-$ and $8 \mathrm{e}$-bonding modes one and also two $\mathrm{C}=\mathrm{N}$ bonds, respectively, are additionally utilized for $\eta^{2}$-coordination to another metal atom $[1,2]$ (see Fig. 2). While there is again relatively little change in the $\mathrm{N}=\mathrm{C}$ bond distances for the $4 \mathrm{e}$ chelating bonding mode with respect to the free ligand, there is extensive bond lengthening for $\mathrm{N}=\mathrm{C}$ bonds which are $\eta^{2}$-coordinated to a metal atom: $\eta^{2}-\mathrm{C}=\mathrm{N}$ bond distances may vary between 1.45 and $1.35 \AA[1,2]$.

In this article we will restrict our discussion mainly to the results of our detailed study of the ruthenium carbonyl-R-DAB (and -R-Pyca) systems, as well as related heterobinuclear metal-R-DAB complexes having mainly the $6 \mathrm{e}$ and $8 \mathrm{e}$ donor bonding modes.

\section{A. Reactions Occurring in the System $R_{3}(C O)_{12} / R$ - DAB}

Discussion of the reactions observed for the system $\mathrm{Ru}_{3}(\mathrm{CO})_{12} / \mathrm{R}-\mathrm{DAB}$ is very illustrative because of the insight one may obtain about the influence of the steric properties of the nitrogen substituted $R$ in R-DAB on the products formed and on the reaction course (see Scheme 1) [1, 2, 16, 17].

The first observable and in some cases isolatable intermediate in the reactions of the $\mathrm{Ru}_{3}(\mathrm{CO})_{12} / \mathrm{R}$ $\mathrm{DAB}$ system is mononuclear $\mathrm{Ru}(\mathrm{CO})_{3}(\mathrm{R}-\mathrm{DAB})$, formed via a number of as yet unknown intermediate steps [17]. Strong indications are the close re- semblance of the IR spectra in the $\nu(\mathrm{CO})$ stretching region with those of $\mathrm{Fe}(\mathrm{CO})_{3}$ (R-DAB), for which a crystal structure was determined for $R=2,6-\mathrm{di}-\mathrm{i}-\mathrm{Pr}$ Me [18], as well as with those of $\mathrm{Ru}(\mathrm{CO})_{3}(\mathrm{R}-\mathrm{DAB})$ which could be isolated for $\mathrm{R}=\mathrm{di}-\mathrm{i}-\mathrm{Pr}-\mathrm{Me}$, mesityl, 2,6-xylyl [1,2].

For other $\mathrm{R}$ groups the $\mathrm{Ru}(\mathrm{CO})_{3}(\mathrm{R}-\mathrm{DAB})$ intermediate reacts further with $\mathrm{Ru}_{3}(\mathrm{CO})_{12}$ to give dinuclear $\mathrm{Ru}_{2}(\mathrm{CO})_{6}(\mathrm{R}-\mathrm{DAB})(\mathrm{R}=\mathrm{i}-\mathrm{Pr}, \mathrm{c}-\mathrm{Hex}, \mathrm{t}-\mathrm{Bu})$ [17]. All available data imply that $\mathrm{Ru}_{2}(\mathrm{CO})_{6}(\mathrm{R}$ $\mathrm{DAB})$ is analogous to $\mathrm{Fe}_{2}(\mathrm{CO})_{6}(\mathrm{t}-\mathrm{Bu}-\mathrm{DAB})$, for which a crystal structure determination has been carried out [19] (see Fig. 2). The R-DAB ligand donates $6 \mathrm{e}\left(\sigma-\mathrm{N}, \mu_{2}-\mathrm{N}^{\prime}, \eta^{2}-\mathrm{C}=\mathrm{N}^{\prime}\right)$ to the $\mathrm{M}_{2}(\mathrm{M}=$ $\mathrm{Fe}[19], \mathrm{Ru}[20,21], \mathrm{Os}_{2}$ [22]) unit. Each metal atom carrics three terminal $\mathrm{CO}$ groups. The metal atoms are connected to each other via a single metalmetal bond (Scheme 1).

Treatment of $\mathrm{Ru}_{2}(\mathrm{CO})_{6}(\mathrm{R}-\mathrm{DAB})(\mathrm{R}=\mathrm{i} \cdot \mathrm{Pr}, \mathrm{c}-\mathrm{Hex})$ with $\mathrm{Me}_{3} \mathrm{NO}$ affords $\mathrm{Ru}_{2}(\mathrm{CO})_{5}(\mathrm{R}-\mathrm{DAB})$, carbon dioxide and $\mathrm{Me}_{3} \mathrm{~N}$ [16]. The $\mathrm{Ru}_{2}(\mathrm{CO})_{5}(\mathrm{R}-\mathrm{DAB})$ could also be prepared directly from $\mathrm{Ru}_{3}(\mathrm{CO})_{12}$ and $\mathrm{R}-\mathrm{DAB}$ for $\mathrm{R}=$ neo-Pe. Furthermore, $\mathbf{R u}_{2}-$ $(\mathrm{CO})_{6}(\mathrm{R}-\mathrm{DAB}) \quad(\mathrm{R}=\mathrm{i}-\mathrm{Pr}, \quad \mathrm{c}-\mathrm{Hex}$, neo-Pe $)$ could be made rapidly by bubbling $C O$ gas through a toluene solution of $\mathrm{Ru}_{2}(\mathrm{CO})_{5}(\mathrm{R}-\mathrm{DAB})$ [16].

Since $\mathrm{Ru}_{2}(\mathrm{CO})_{5}(\mathrm{R}-\mathrm{DAB})$ contains one $\mathrm{CO}$ group less than $\mathrm{Ru}_{2}(\mathrm{CO})_{6}(\mathrm{R}-\mathrm{DAB})$ one would expect an 8e-donor mode for R-DAB in the former compound, which indeed could be crystallographically ascertained for $\mathrm{Ru}_{2}(\mathrm{CO})_{5}(\mathrm{i}-\mathrm{Pr}-\mathrm{DAB})$ [16]. In this complex a $\mathrm{Ru}-\mathrm{Ru}$ bond of $2.741(1) \AA$ is bridged by an $8 \mathrm{e}$ R-DAB donor $\left(\sigma-\mathrm{N}, \sigma-\mathrm{N}^{\prime}, \eta^{2}-\mathrm{C}=\mathrm{N}, \eta^{2}-\right.$ $\mathrm{C}^{\prime}=\mathrm{N}^{\prime}$ ) and by one asymmetric bonded carbonyl group (see Scheme 1). Each $\mathrm{Ru}$ atom carries two further terminal $\mathrm{CO}$ groups. The $\mathrm{N}=\mathrm{C}-\mathrm{C}=\mathrm{N}$ skcleton is virtually flat with $\mathrm{C}=\mathrm{N}$ and $\mathrm{C}-\mathrm{C}$ bond distances of $1.43(1) \AA$ (mean) and 1.39(2) $\AA$, respectively. These bond distances indicate that the LUMO of the R-DAB ligand, which has bonding character between the two central $C$ atoms and which is antibonding between the $\mathrm{C}$ and $\mathrm{N}$ atoms, is extensively occupied. The ${ }^{1} \mathrm{H}$ NMR absorptions of both imine $\mathrm{H}$-atoms are equivalent and give one singlet at about $6 \mathrm{ppm}$. This is in contrast to $\mathrm{Ru}_{2}$ $(\mathrm{CO})_{6}(\mathrm{R}-\mathrm{DAB})$ in which the imine $\mathrm{H}$-atom of the $\sigma-\mathrm{N}$ bonded $\mathrm{C}=\mathrm{N}$ part absorbs at about $8 \mathrm{ppm}$, while the imine $\mathrm{H}$-atom of the $\eta^{2}-\mathrm{C}=\mathrm{N}$ bonded moiety appears at about 4 ppm [20-22]. In Table $\mathrm{I}$ the ${ }^{1} \mathrm{H}$ - and ${ }^{13} \mathrm{C}-\mathrm{NMR}$ absorptions of the imine ${ }^{1} \mathrm{H}$-atoms and ${ }^{13} \mathrm{C}$-atoms are recorded for various coordination modes of the $\mathrm{R}-\mathrm{DAB}$ group.

The mixed complexes FeRu(CO) 6 (R-DAB) (R $=\mathrm{i}-\mathrm{Pr}, \mathrm{c}-\mathrm{Hex}, \mathrm{t}-\mathrm{Bu})$ could be prepared from $\mathrm{Ru}_{2}(\mathrm{CO})_{5}(\mathrm{R}-\mathrm{DAB})$ and $\mathrm{Fe}_{2}(\mathrm{CO})_{9}$ [16]. Although it is not clear toward which metal atom the R-DAB ligand is $\eta^{2}-\mathrm{C}=\mathrm{N}$ coordinated, it appears likely on the basis of spectroscopic measurements [16] that 


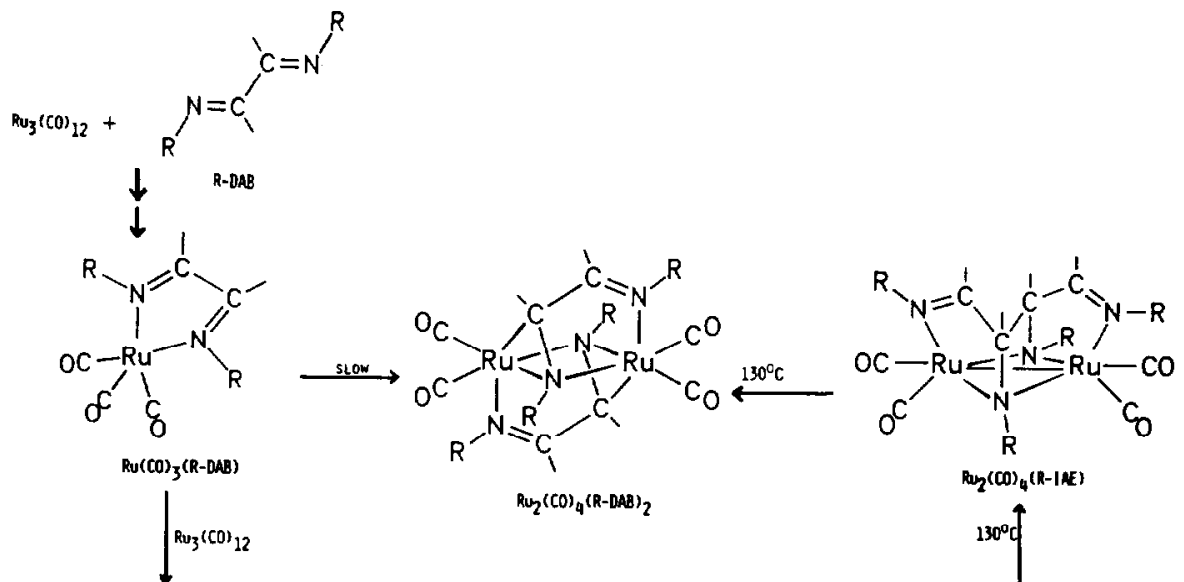

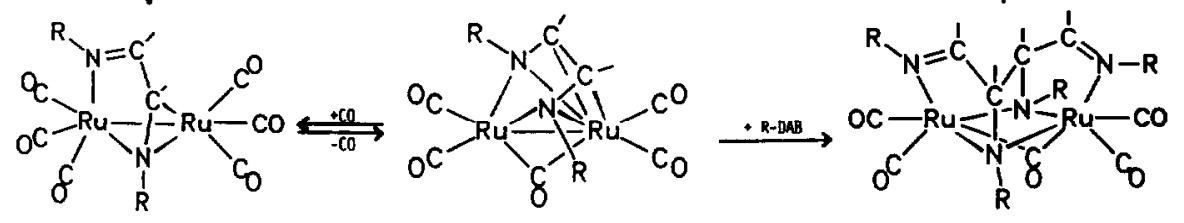

Ans $(C O)_{6}\left(R-D B^{2}\right)$

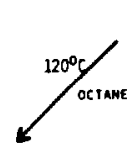

$\mathrm{Rn}_{2}(\mathrm{CO})_{5}(\mathrm{R}-\mathrm{ABB})$

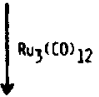

$\mathrm{m}_{2}\left(\mathrm{CO}_{5}(\mathrm{R}-1 \mathrm{HE})\right.$

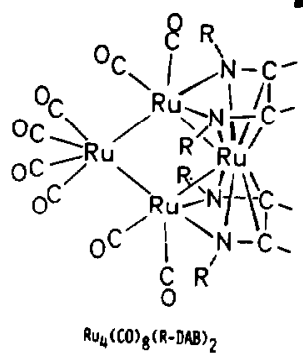

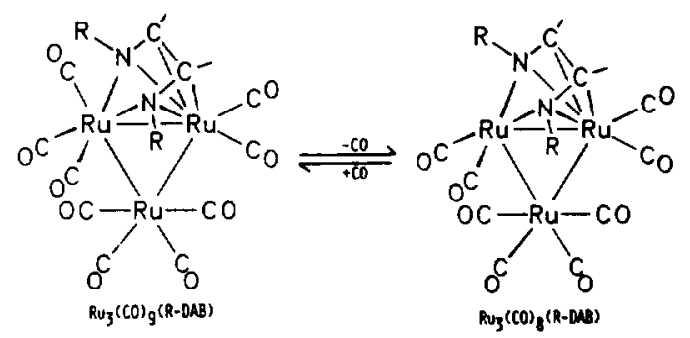

Scheme 1. Reactions occurring in the system $\mathrm{Ru}_{3}(\mathrm{CO})_{12} / \mathrm{R}-\mathrm{DAB}$. The pathways chosen depend on $\mathrm{R}$ and the concentrations of reagents present in solution (see text).

TABLE I. ${ }^{1} \mathrm{H}$ and ${ }^{13} \mathrm{C}$ NMR Chemical Shifts for R-DAB Both (imine-H and imine-C) as a Free Ligand and in Various Coordination Modes $\left(\delta\right.$ in ppm) ${ }^{\mathrm{a}}$.

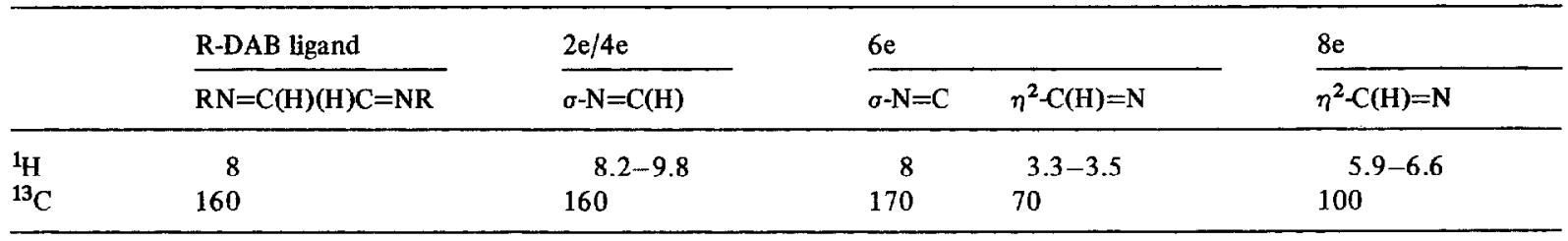

aTS internal standard.

R-DAB is $\sigma-\mathrm{N}$ coordinated to $\mathrm{Ru}$ and $\eta^{2}-\mathrm{C}=\mathrm{N}$ coordinated to $\mathrm{Fe}$.

When $R_{2}(C O)_{5}(\mathrm{R}-\mathrm{DAB})$ is heated on its own in octane the tetranuclear complex $\mathrm{Ru}_{4}(\mathrm{CO})_{8}(\mathrm{R}$ $D A B)_{2}$ is obtained in very high yields $(R=i-P r$, c-Hex, nco-Pc) $[16,23]$. The crystal structure of the complex for $R=i-P r$ shows the presence of a butterfly array of four $\mathrm{Ru}$ atoms with four $\mathrm{Ru}-\mathrm{Ru}$ bonds ranging between 2.838(2) $\AA$ and 2.848(2) $\AA$. The $\mathrm{C}=\mathrm{N}$ distances (1.41(3) $\AA$ (mean)) and $\mathrm{C}-\mathrm{C}$ distance (1.42(3) $\AA$ ) imply strong backbonding to both 8e-R-DAB donor ligands. The total number of valence electrons of $64 \mathrm{e}$ is in agreement with the presence of four $R u-R u$ single bonds. A surprising feature is that these tetranuclear complexes are formed in such high yields, which indicates a kinetically efficient pathway for the dimerisation process. Although one may envisage that it will be not too difficult to dissociate one $\mathrm{CO}$ group to form $\mathrm{Ru}_{2}(\mathrm{CO})_{4}(\mathrm{R}-\mathrm{DAB})$ which then can dimerise, 
it is astounding that such a large rearrangement occurs with the observed high efficiency. The extent of rearrangement is evident from the structure in which one $\mathrm{Ru}$ atom does not carry $\mathrm{CO}$ groups, while another $\mathrm{Ru}$ atom does not possess coordinating R-DAB groups at all. Finally it is of interest to mention that one may recognize in the structure a pseudo ferrocene unit $\mathrm{Ru}[\mathrm{RuN}=\mathrm{C}-\mathrm{C}=\mathrm{N}]_{2}$ (see Figure in Scheme 1).

When $\mathrm{Ru}_{2}(\mathrm{CO})_{\mathrm{n}}(\mathrm{R}-\mathrm{DAB})(\mathrm{n}=6,5)$ is heated in the presence of $\mathrm{Ru}_{3}(\mathrm{CO})_{12}$, trinuclear compounds of the type $\mathrm{Ru}_{3}(\mathrm{CO})_{\mathrm{m}}(\mathrm{R}-\mathrm{DAB})(\mathrm{m}=9,8)$ are obtained (see Scheme 1) [17]. It was found that $\mathrm{Ru}_{3}$ $(\mathrm{CO})_{\mathrm{m}}(\mathrm{R}-\mathrm{DAB})$ could be made directly from $\mathrm{Ru}_{3}(\mathrm{CO})_{12}$ and R-DAB ( $\mathrm{R}=\mathrm{i}-\mathrm{Pr}, \mathrm{c}-\mathrm{Hex}, \mathrm{t}-\mathrm{Bu}$, neoPe). After the formation of the first observable intermediate $\mathrm{Ru}(\mathrm{CO})_{3}(\mathrm{R}-\mathrm{DAB})$, dimerization occurs to $\mathrm{Ru}_{2}(\mathrm{CO})_{5}(\mathrm{R}-\mathrm{DAB})$ which with $\mathrm{Ru}_{3}(\mathrm{CO})_{12}$ leads to $\mathrm{Ru}_{3}(\mathrm{CO})_{9}(\mathrm{R}-\mathrm{DAB})$ and/or $\mathrm{Ru}_{3}(\mathrm{CO})_{8}(\mathrm{R}-\mathrm{DAB})$, depending on the applied temperature and concentrations of reactants used. In fact it could be demonstrated that red $\mathrm{Ru}_{3}(\mathrm{CO})_{9}(\mathrm{R} \cdot \mathrm{DAB})$ and green $\mathrm{Ru}_{3}(\mathrm{CO})_{8}(\mathrm{R}-\mathrm{DAB})$ are in facile equilibrium with each other:

$$
\mathrm{Ru}_{3}(\mathrm{CO})_{8}(\mathrm{R}-\mathrm{DAB}) \underset{\text { green }}{\stackrel{\mathrm{N}_{2}}{\rightleftarrows}} \mathrm{Ru}_{3}(\mathrm{CO})_{9}(\mathrm{R}-\mathrm{DAB})
$$

The molecular geometry of $\mathrm{Ru}_{3}(\mathrm{CO})_{9}$ (c-HexDAB) contains one normal single $R u-R u$ bond of $2.793(1) \AA$ and two longer bonds of $2.956(1)$ and $3.026(1) \AA$. The $R u-R u$ bond of $3.026(1) \AA$ is bridged by a symmetrically bonded c-Hex-DAB group with $\mathrm{N}=\mathrm{C}$ and $\mathrm{C}-\mathrm{C}$ distances of about 1.39 $\AA$ and 1.386(11) $\AA$, respectively [17].

Of interest is that in the case of $\mathrm{Ru}_{3}(\mathrm{CO})_{8}$ (neoPe-DAB) the R-DAB ligand is also symmetrically bonded as a $8 \mathrm{e}$ donor ligand, but now bridges a $\mathrm{Ru}-$ Ru single bond of the expected bond length of 2.825(1) $\AA$, while the other two $\mathrm{Ru}-\mathrm{Ru}$ bonds are $2.768(1)$ and $2.737(1) \AA$, respectively. The relations between both structures are demonstrated in Table II, together with the molecular geometries [17].

The complex $\mathrm{Ru}_{3}(\mathrm{CO})_{8}$ (neo-Pe-DAB) therefore has a geometry as expected for a 48 e-cluster with normal $\mathrm{Ru}-\mathrm{Ru}$ and $\mathrm{Ru}-$ ligand bond lengths.

It is of interest to note that in $\mathrm{Ru}_{3}(\mathrm{CO})_{8}$ (neo$\mathrm{Pe}-\mathrm{DAB}$ ) there is, trans to the $\mathrm{Ru}(2)-\mathrm{Ru}(3)$ bond, an empty position on $\mathrm{Ru}(2)$ which becomes filled in $\mathrm{Ru}_{3}(\mathrm{CO})_{9}(\mathrm{c}-\mathrm{Hex}-\mathrm{DAB})$. The overall structure of the latter compound seems to be at first sight hardly changed with respect to $\mathrm{Ru}_{3}(\mathrm{CO})_{8}$ (neo-PeDAB) [17]. The distances, however, in the complexes do change significantly around the $\operatorname{Ru}(2)$ atom; in particular the $R u(2)-R u(3), R u(2)-R u(1)$ and $\mathrm{Ru}(2)-\mathrm{CO}$ bond lengths, as is obvious from Table

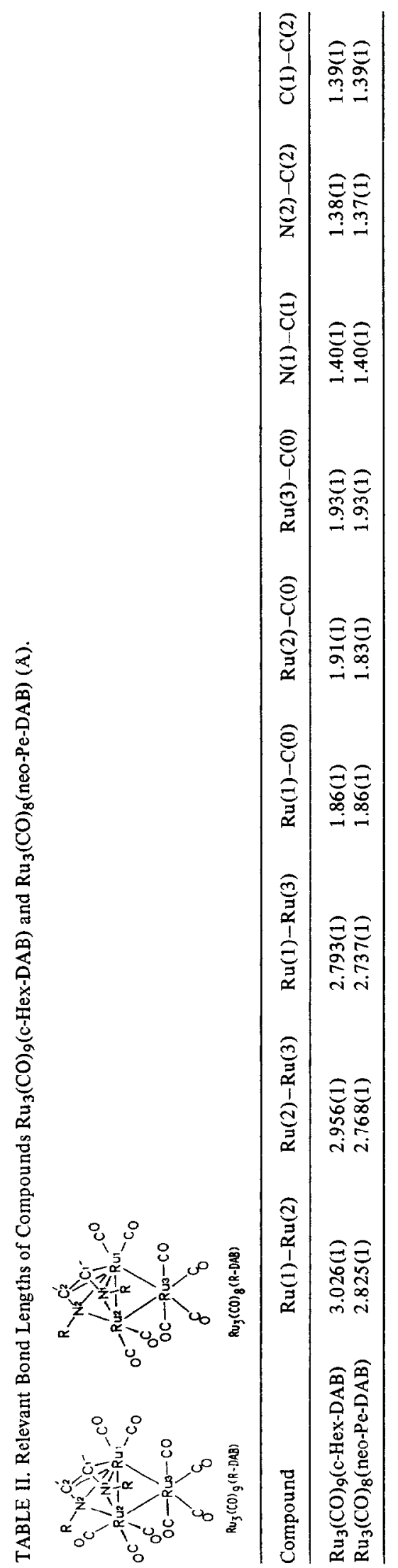


II. The formation of the $50 \mathrm{e} \mathrm{Ru}_{3}(\mathrm{CO})_{9}$ (R-DAB) cluster clearly leads to partial occupation of the LUMO in the $\mathrm{Ru}_{3}$ cluster with electron localization on $\operatorname{Ru}(2)$. This is rather surprising, since in first instance we would have expected two other possibilities for $\mathrm{Ru}_{3}(\mathrm{CO})_{9}(\mathrm{R}-\mathrm{DAB})$. A first possibility is a structure with three normal $\mathbf{R u}-\mathbf{R u}$ single bonds, but with R-DAB acting as a 6e-donor and consequently with the added $\mathrm{CO}$ molecule bonded to $\mathrm{Ru}(1)$ (Fig. 3).

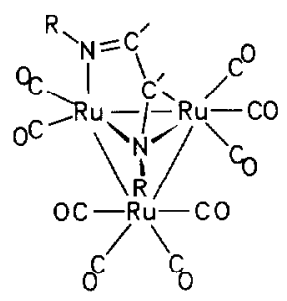

Fig. 3. One of the expected structures for $\mathrm{Ru}_{3}(\mathrm{CO})_{9}(\mathrm{R}$ DAB). For the actual structure see Table II.

A second possibility would comprise a structure with R-DAB as an 8e-donor, but with one ruptured $\mathbf{R u}-\mathbf{R u}$ bond. In contrast in the actual structure neither a metal-metal bond nor a metal-ligand bond is ruptured completely. A further point of interest is that $\mathrm{Ru}_{3}(\mathrm{CO})_{8}(\mathrm{R}-\mathrm{DAB})$ is isostructural with $\mathrm{Ru}_{2}(\mathrm{CO})_{5}(\mathrm{R}-\mathrm{DAB})$, since a $\mu_{2}-\mathrm{CO}$ group in the latter compound has been replaced by a $\mu_{2}$ $\mathrm{Ru}(\mathrm{CO})_{4}$ group. Reaction of $\mathrm{Ru}_{2}(\mathrm{CO})_{5}$ (R-DAB) with $\mathrm{CO}$ caused the R-DAB group to change from a $8 \mathrm{e}$ to a 6e-donor situation, while the bridging $\mathrm{CO}$ group becomes terminal. Both the starting compound and the end product have a 36 electron count with 18 electrons on each metal atom.

In the case of the reaction of $\mathrm{Ru}_{3}(\mathrm{CO})_{8}(\mathrm{R}-\mathrm{DAB})$ with $\mathrm{CO}$ the $\mu_{2}-\mathrm{Ru}(\mathrm{CO})_{4}$ group cannot move to a terminal position and the compound remains trinuclear with a $20 \mathrm{e}$ configuration on $\mathrm{Ru}(2)$, whether or not R-DAB is in the $8 \mathrm{e}$ or $6 \mathrm{e}$ donor mode. Only by migration of $\mathrm{CO}$ from $\mathrm{Ru}(2)$ to $\mathrm{Ru}(1)$ could the situation be corrected provided that the R-DAB becomes a 6e-donor, as shown in Fig. 3. For reasons not understood at this moment, this migration does not occur.

From the available evidence it is clear that the R-group determines to a great extent the product formation and therefore the reaction routes (Scheme 1 and $R$ specified in the text). For example, when $\mathrm{R}$ is doubly branched at both the $\mathrm{C}^{\alpha}$ and $\mathrm{C}^{\beta}$ positions in the R-group, which is bonded to the imine N-atom, there is a strong shielding of the $\pi$-bonds of the $\mathrm{NCCN}$ skeleton, thereby making $\eta^{2}-\mathrm{C}=\mathrm{N}$ metal bonding very difficult indeed. Therefore $\mathrm{Ru}(\mathrm{CO})_{3^{-}}$ (R-DAB) is the only product for $\mathrm{R}=$ di-i-Pr-Me; $2,4,6-\mathrm{Mes}$ and 2,6-xylyl $[16,17,23]$. When $R$ is triply branched at $\mathrm{C}^{\alpha}(\mathrm{R}=\mathrm{t}-\mathrm{Bu})$ almost always $6 \mathrm{e}$
$\left(\sigma-\mathrm{N}, \quad \mu_{2}-\mathrm{N}^{\prime}, \quad \eta^{2}-\mathrm{C}=\mathrm{N}^{\prime}\right)$ coordination occurs with one exception in the case of $\mathrm{Mn}_{2}(\mathrm{CO})_{6}(\mathrm{t}-\mathrm{Bu}-\mathrm{DAB})$ [24] (vide infra). When $R$ is doubly branched at $\mathrm{C}^{\alpha}$ and not or singly branched at $\mathrm{C}^{\beta}$, both $6 \mathrm{e}$ and $8 \mathrm{e}$ coordination are possible alternatives.

Finally, when $R$ is singly branched at $C^{\alpha} 8 \mathrm{e}$-donor bonding is predominant. It appears that branching at $C^{\beta}$ does not have much influence in the last case, since for $\mathrm{R}=$ neo-Pe and $\mathrm{R}=\mathrm{i}-\mathrm{Bu}$ analogous compounds with 8e R-DAB ligands are formed $[16,17$, 23]. It may be concluded in fact that when bonded to low valent metal atoms like $\mathrm{Ru}^{\circ}$ and provided that a $M_{2}$ pair is available for bonding, the R-DAB ligand favours $8 \mathrm{e}$-coordination over $6 \mathrm{e}$ bonding.

\section{B. Reactions of Selected Ruthenium Carbonyl R- DAB Compounds}

\section{Reaction of $\mathrm{Ru}_{3}(\mathrm{CO})_{8}(\mathrm{R}-\mathrm{DAB})$ with $\mathrm{CH}_{2} \mathrm{~N}_{2}$}

The empty coordination site on the $\operatorname{Ru}(2)$ atom of $\mathrm{Ru}_{3}(\mathrm{CO})_{8}(\mathrm{R}-\mathrm{DAB})$ which can be filled easily and reversibly with $\mathrm{CO}$, as we have seen before, prompted us to investigate its reactivity towards other substrates. An obvious choice is then the carbene fragment.

Treatment of $\mathrm{Ru}_{3}(\mathrm{CO})_{8}(\mathrm{R}-\mathrm{DAB}) \quad(\mathrm{R}=$ neo-Pe, i-Bu) with $\mathrm{CH}_{2} \mathrm{~N}_{2}$ yielded at room temperature the compound $\left(\mu-\mathrm{CH}_{2}\right) \mathrm{Ru}_{3}(\mathrm{CO})_{8}(\mathrm{R}-\mathrm{DAB})$ in good yields [25]. The crystal structure determination for $\mathrm{R}$ is neo-Pe and showed the presence of a butterfly array of the $\mathrm{Ru}_{3} \mathrm{C}$ unit with two $\mathrm{Ru}-\mathrm{Ru}$ bonds $(\mathrm{Ru}(1)-\mathrm{Ru}(2)$ is $2.8690(6) \AA$ and $\mathrm{Ru}(1)-\mathrm{Ru}(3)$ is $2.9079(6) \AA$, while $\operatorname{Ru}(2) \cdots \operatorname{Ru}(3)$ is $3.1021(6)$ $\AA$ and clearly non-bonding (Fig. 4.)).

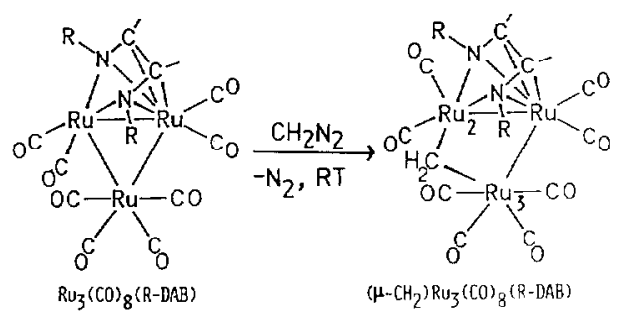

Fig. 4. The schematic structure of $\left(\mu-\mathrm{CH}_{2}\right) \mathrm{Ru}_{3}(\mathrm{CO})_{8}$ (neo$\mathrm{Pe}-\mathrm{DAB}$ ) formed from $\mathrm{Ru}_{3}(\mathrm{CO})_{8}(\mathrm{R}-\mathrm{DAB})$ and $\mathrm{CH}_{2} \mathrm{~N}_{2}$.

The $R u(2) \cdots R u(3)$ pair is clearly asymmetrically bridged by the $\mathrm{CH}_{2}$ moiety with $\mathrm{Ru}(2)-\mathrm{C} 2.048(5)$ and $\mathrm{Ru}(3)-\mathrm{C} 2.204(6) \AA$. The flat R-DAB skeleton is $8 \mathrm{e}$ bonded to the $\mathrm{Ru}(1)-\mathrm{Ru}(2)$ pair, as is clear from the $\mathrm{C}=\mathrm{N}$ and $\mathrm{C}-\mathrm{C}$ bond lengths of 1.38(1) $\AA$ of the NCCN unit. The rupture of one $\mathrm{Ru}-\mathrm{Ru}$ bond in $\mathrm{Ru}_{3}(\mathrm{CO})_{8}(\mathrm{R}-\mathrm{DAB})$ resulting in $\left(\mu-\mathrm{CH}_{2}\right) \mathrm{Ru}_{3}$ $(\mathrm{CO})_{8}(\mathrm{R}-\mathrm{DAB})$ is in line with the addition of a $2 \mathrm{e}$ carbene donor.

${ }^{1} \mathrm{H}$ NMR spectra show the appearance of the $\mathrm{CH}_{2}$ hydrogen atoms at $3.7 \mathrm{ppm}$, in line with 
expectations for $\mu$ - $\mathrm{C}(\mathrm{H}) \mathrm{R}$ groups [26, 27] bridging non-bonded metal pairs. Values between 5 and 11 ppm are normally found for $\mu-\mathrm{C}(\mathrm{H}) \mathrm{R}$ groups bridging metal-metal bonded $\mathrm{M}_{2}$ pairs. ${ }^{13} \mathrm{C}$ NMR spectra show the carbene resonance at $32 \mathrm{ppm}$, which is as expected. The imine ${ }^{13} \mathrm{C}$ resonances of the $8 \mathrm{e} R$ DAB ligand appears as one signal at $100 \mathrm{ppm}$ (Table I). The single absorption is due to a flying movement of the 'butterfly' structure of the compound which could not be frozen out on the NMR time scale.

Although the reaction route of the carbene addition is not known, it seems likely that the $\mathrm{CH}_{2}$ group formed first attacks the open position on $\mathrm{Ru}(2)$ of $\mathrm{Ru}_{3}(\mathrm{CO})_{8}(\mathrm{R}-\mathrm{DAB})$ (Scheme 1). Subsequently the $\mathrm{CH}_{2}$ group shifts to the bridging position. The compound $\mathrm{CPh}_{2} \mathrm{~N}_{2}$ does not react with $\mathrm{Ru}_{3}(\mathrm{CO})_{8}(\mathrm{R}-\mathrm{DAB})$, which is probably due to not only the lower reactivity of the $\mathrm{CPh}_{2}$ group, but mainly to the size of this group.

\section{Reactions of $R u_{3}(C O)_{8}(R-D A B)$ and of $R u_{2}(C O)_{5^{-}}$ (R-DAB) towards $\mathrm{H}_{2}$}

Because of the easy availability of an (open) coordination site in $\mathrm{Ru}_{2}(\mathrm{CO})_{5}(\mathrm{R}-\mathrm{DAB})$ and its presence in $\mathrm{Ku}_{3}(\mathrm{CO})_{8}(\mathrm{R}-\mathrm{DAB})$, reactions with $\mathrm{H}_{2}$ were carried out in order to investigate whether the coordinated R-DAB ligand could be hydrogenated or not [28]. From the following it is clear that hydrogenation does not occur, but instead the formation of metal hydrides and rearrangements in the coordination mode of R-DAB and/or in the metal cluster are observed.

The complex $\mathrm{Ru}_{2}(\mathrm{CO})_{5}(\mathrm{R}-\mathrm{DAB})(\mathrm{R}=\mathrm{i}-\mathrm{Pr}, \mathrm{c}-\mathrm{Hex}$, c-Hex-Me) reacts smoothly at $90{ }^{\circ} \mathrm{C}$ with molecular $\mathrm{H}_{2}$ to yield $\mathrm{H}_{2} \mathrm{Ru}_{2}(\mathrm{CO})_{5}(\mathrm{R}-\mathrm{DAB})$, which could also be prepared directly from $\mathrm{Ru}_{2}(\mathrm{CO})_{6}(\mathrm{R}-\mathrm{DAB})$ $(\mathrm{R}=\mathrm{i}-\mathrm{Pr}, \mathrm{c}-\mathrm{Hex}, \mathrm{t}-\mathrm{Bu})$.

The proposed structure is shown in Fig. 5. The two hydride atoms are terminally bonded in a cis-

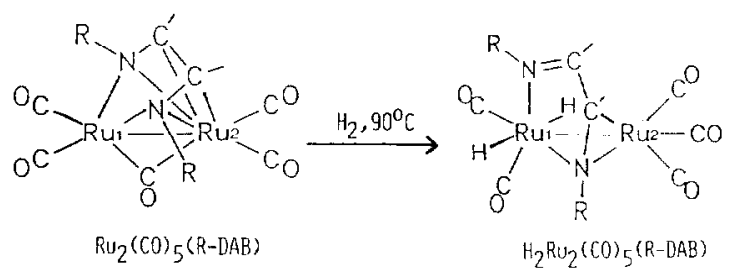

Fig. 5. Reaction of $\mathrm{Ru}_{2}(\mathrm{CO})_{5}(\mathrm{R}-\mathrm{DAB})$ with $\mathrm{H}_{2}$ to give $\mathrm{H}_{2} \mathrm{Ru}_{2}(\mathrm{CO})_{5}$ (R-DAB) of which the structure is schematically shown.

position to the $\mathrm{Ru}$ atom having the $\mathrm{N}$ atoms of the R-DAB ligand $\sigma-\mathrm{N}$ bonded. The ${ }^{1} \mathrm{H}$ NMR signals of the hydride atoms absorb at -7.5 and $11.7 \mathrm{ppm}$ with $J_{\mathbf{H}-\mathbf{H}}($ cis $)$ of $6 \mathrm{~Hz}$. The R-DAB ligand has thus changed its coordination from a $8 \mathrm{e}$ - to $6 \mathrm{e}$ donor mode. The structure of $\mathrm{H}_{2} \mathrm{Ru}_{2}(\mathrm{CO})_{5}(\mathrm{R}-\mathrm{DAB})$ is therefore very similar to that of $\mathrm{Ru}_{2}(\mathrm{CO})_{6}(\mathrm{R}$ DAB).

The reaction is more complicated when $\mathrm{Ru}_{3}$ $(\mathrm{CO})_{8}(\mathrm{R}-\mathrm{DAB})$ is treated with $\mathrm{H}_{2}$. In Fig. 6 it is shown that $\mathrm{H}_{2} \mathrm{Ru}_{4}(\mathrm{CO})_{8}(\mathrm{R}-\mathrm{DAB})_{2}$ is formed in addition to $\mathrm{H}_{4} \mathrm{Ru}_{4}(\mathrm{CO})_{12}$ [28].
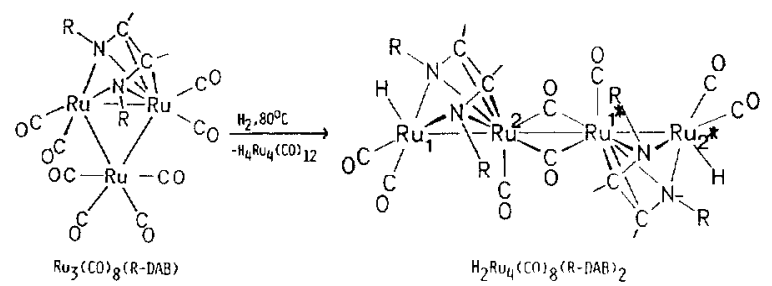

Fig. 6. The schematic structure of $\mathrm{H}_{2} \mathrm{Ru}_{4}(\mathrm{CO})_{8}$ (neo-Pe$\mathrm{DAB})_{2}$ as formed in the reaction of $\mathrm{Ru}_{3}(\mathrm{CO})_{8}$ (neo-PeDAB) with $\mathrm{H}_{2}$.

The crystal structure determination for $\mathrm{R}=$ neo-Pe shows the first example of a linear chain of four $\mathrm{Ru}$ atoms (Ru(1)-Ru(2) 2.806(2) $\AA$ and $\operatorname{Ru}(2)-\operatorname{Ru}(2)^{*} 2.745(2) \AA$ ), while the $\mathrm{Ru}(1)$ $\mathrm{Ru}(2)-\mathrm{Ru}(2)^{*}$ angle is $176.48(6)^{\circ}$. The central $\mathrm{Ru}(2)-\mathrm{Ru}(2)^{*}$ bond is bridged by two CO groups, while the other $\mathrm{CO}$ groups are terminal bonded. The $R u(1)-R u(2)$ and $R u(1)^{*}-R u(2)^{*}$ bonds are bridged by a flat R-DAB skeleton with $\mathrm{N}=\mathrm{C}$ bond lengths and $\mathrm{C}-\mathrm{C}$ bond lengths of 1.35(2) $\AA$ and 1.39(2) $\AA$, respectively. The hydride positions could be deduced indirectly from the structural data, since there are distinct gaps in the coordination spheres around $\mathrm{Ru}(1)$ and $\mathrm{Ru}(1)^{*}$. Also the $\mathrm{Ru}-\mathrm{Ru}$ bond distances are normal for a single metal-metal bond, indicating the absence of bridging $\mathrm{H}$-atoms. Finally, ${ }^{1} \mathrm{H}$ NMR data indicate the presence of terminal $\mathrm{H}$-atoms because of a single absorption at $-10 \mathrm{ppm}$.

The linear array of four Ru atoms is in agreement with the fact that the cluster contains 66 valence electrons, i.e. three pairs more than required for a tetrahedral arrangement of metal atoms [28].

With regards to the mechanism of formation of the $\mathrm{Ru}_{4}$ cluster a few remarks can be made. Firstly, $\mathrm{H}_{2} \mathrm{Ru}_{4}(\mathrm{CO})_{8}$ (neo-Pe-DAB $)_{2}$ can also be formed from $\mathrm{Ru}_{2}(\mathrm{CO})_{5}$ (neo-Pe-DAB) and $\mathrm{H}_{2}$ via the unstable intermediate $\mathrm{H}_{2} \mathrm{Ru}_{2}(\mathrm{CO})_{5}$ (neo-Pe-DAB) which can be ubserved in solution. In this reaction $\mathrm{CO}$ and $\mathrm{H}_{2}$ are also eliminated. Secondly, reaction of $\mathrm{Ru}_{3}$ $(\mathrm{CO})_{8}$ (R-DAB) with $\mathrm{H}_{2}$ gives not only the $\mathrm{Ru}_{4}$ complex, but also $\mathrm{H}_{4} \mathrm{Ru}_{4}(\mathrm{CO})_{12}$.

It appears therefore not unreasonable to assume that $\mathrm{H}_{2}$ is coordinated to $\mathrm{Ru}_{3}(\mathrm{CO})_{8}(\mathrm{R}-\mathrm{DAB})$ in the open coordination position of $\mathrm{Ru}(2)$ (vide supra). Such $\mathrm{H}_{2}$ adducts are now known in the case of $\mathrm{H}_{2}$ $\mathrm{W}(\mathrm{CO})_{3}\left\{\mathrm{P}(\mathrm{i}-\mathrm{Pr})_{3}\right\}_{2}[29]$.

The coordination of $\mathrm{H}_{2}$ leads to a $50 e \mathrm{H}_{2} \mathrm{Ru}_{3}$. $(\mathrm{CO})_{8}$ (R-DAB) species with concomitant destabilization of the $\mathrm{Ru}_{3}$ cluster. Decomposition subsequently 
occurs to $\mathrm{HRu}_{2}(\mathrm{CO})_{4}(\mathrm{R}-\mathrm{DAB})$, which dimerizes to $\mathrm{H}_{2} \mathrm{Ru}_{4}(\mathrm{CO})_{8}(\mathrm{R}-\mathrm{DAB})$, and $\mathrm{HRu}(\mathrm{CO})_{4}$ which tetramerizes to $\mathrm{H}_{4} \mathrm{Ru}_{4}(\mathrm{CO})_{12}$.

\section{Activation of the Coordinated R-DAB Ligand}

In this section we discuss various ways in which the metal coordinated R-DAB ligand may couple with other unsaturated double and triple bond systems.

Coupling of Two R-DAB Ligands to form the IAE Ligand (IAE = bis-(1-alkylimino)-2-(alkylamino)ethane- $\left.N, N^{\prime}\right)$

The first observed complex containing the IAE ligand is $\mathrm{Mo}_{2}(\mathrm{CO})_{6}(\mathrm{IAE})$, which was prepared by the following two routes [30].

$$
\begin{array}{r}
2 \mathrm{MnBr}(\mathrm{CO})_{3}(\mathrm{R}-\mathrm{DAB})+2\left[\mathrm{Mo}(\mathrm{CO})_{4}(\mathrm{R}-\mathrm{DAB})\right] \mathrm{K} \longrightarrow \\
\mathrm{Mo}_{2}(\mathrm{CO})_{6}(\mathrm{IAE})+2 \mathrm{R}-\mathrm{DAB}+2 \mathrm{KBr}+\mathrm{Mn}_{2}(\mathrm{CO})_{10}
\end{array}
$$

$$
\begin{aligned}
& 2 \mathrm{MnBr}(\mathrm{CO})_{5}+2\left[\mathrm{Mo}(\mathrm{CO})_{4}(\mathrm{R}-\mathrm{DAB})\right] \mathrm{K} \\
& \mathrm{Mo}_{2}(\mathrm{CO})_{6}(\mathrm{IAE})+2 \mathrm{CO}+2 \mathrm{KBr}+\mathrm{Mn}_{2}(\mathrm{CO})_{10}
\end{aligned}
$$

It was shown for both cases that an unstable intermediate $\mathrm{Mo}-\mathrm{Mn}$ bonded complex is formed first, which then decomposes to form $\mathrm{Mo}_{2}(\mathrm{CO})_{6}(\mathrm{IAE})$. It was also discovered that the IAE ligand, which consists of two $\mathrm{C}-\mathrm{C}$ coupled R-DAB ligands, is produced exclusively from the R-DAB bonded to Mo indicating the formation of an intermediate containing a $\mathrm{Mo}_{2}$ pair on which the coupling occurs. The highest yields of the complex were obtained by the reaction of $\mathrm{Hg}\left[\mathrm{Mo}(\mathrm{CO})_{3}(\mathrm{R}-\mathrm{DAB})\right]_{2}$ with acids $(\mathrm{R}=\mathrm{i}-\mathrm{Pr}, \mathrm{c}-\mathrm{Hex}, \mathrm{t}-\mathrm{Bu})$.

$$
\begin{aligned}
\mathrm{Hg}\left[\mathrm{Mo}(\mathrm{CO})_{3}(\mathrm{R}-\mathrm{DAB})\right]_{2} & +2 \mathrm{H}^{+} \longrightarrow \\
& \mathrm{Mo}_{2}(\mathrm{CO})_{6}(\mathrm{IAE})+\mathrm{H}_{2}+\mathrm{Hg}^{2+}
\end{aligned}
$$

The crystal structure determination of $\mathrm{Mo}_{2}(\mathrm{CO})_{6}$ (IAE) for $\mathrm{R}=\mathrm{i}$-Pr shows a Mo-Mo bond with three terminal CO groups on each Mo-atom and a bridging 10e IAE ligand (Fig. 7). The bond distance of the single Mo-Mo bond is 2.813(3) $\AA$. The $\mathrm{C}-\mathrm{C}$ bond lengths of the $\mathrm{C}-\mathrm{C}$ bond linking the two R-DAB units is 1.61(2) $\AA$ [30]. This $\mathrm{C}-\mathrm{C}$ bond may be cleaved again by heating or irradiating the complex in solution.

It is remarkable that $\mathrm{Cr}_{2}(\mathrm{CO})_{6}$ (IAE) could be prepared in only very small yields, while the tungsten analogue could not be formed at all by the above reactions [30]. This is probably due to the inherent lability of the $\mathrm{C}-\mathrm{C}$ bonds with respect to bond breaking, as will be discussed later for $\mathrm{Ru}$ [20] and $\mathrm{Zn} \mathrm{[31].} \mathrm{Finally,} \mathrm{it} \mathrm{should} \mathrm{be}$ noted that coupling occurs regiospecifically, since

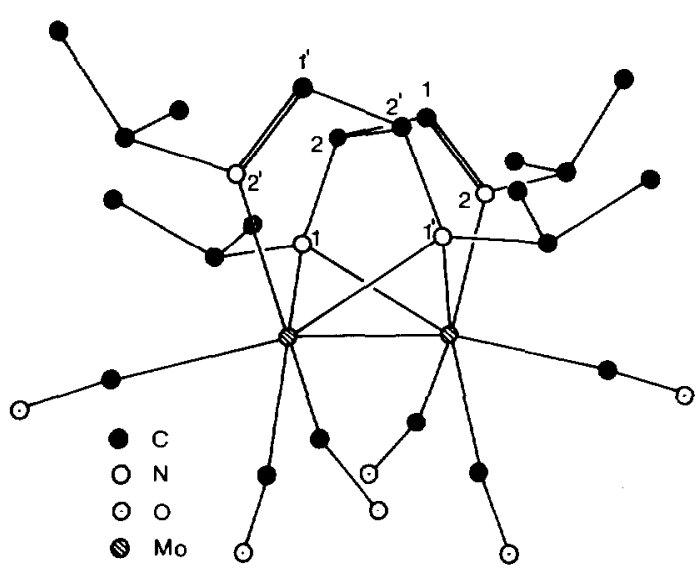

Fig. 7. Structure of $\mathrm{Mo}_{2}(\mathrm{CO})_{6}(\mathrm{IAE})$ (IAE $=\mu$-(1-isopropylamino)-2-(isopropylimino)ethane-N, $N^{\prime}$ ).

the use of R-DAB $\left\{\mathrm{H}, \mathrm{CH}_{3}\right\}$ only gives a product in which the $\mathrm{HC}=\mathrm{N}$ groups are $\mathrm{C}-\mathrm{C}$ coupled to each other.

A further intriguing reaction leading to the IAE formation was observed for $\mathrm{Ru}$ and can be discussed by means of Scheme 1 [20]. It is shown that reaction of $\mathrm{Ru}_{2}(\mathrm{CO})_{5}(\mathrm{R}-\mathrm{DAB})$ with R-DAB leads to $\mathrm{Ru}_{2}(\mathrm{CO})_{5}(\mathrm{IAE})(\mathrm{R}=\mathrm{i}-\mathrm{Pr}, \mathrm{c}-\mathrm{Hex})$. A crystal structure determination of an analogous compound $\mathrm{Ru}_{2}(\mathrm{CO})_{5}(\mathrm{APM}) \quad[32,33]$ (APM stands for bis $[\mu-$ isopropylamino)-(2-pyridyl)methane-N]) shows the presence of a 10e donor APM ligand in which the two pyridine-imine ligands are $\mathrm{C}-\mathrm{C}$ coupled to each other. From all available evidence it is clcar that $\mathrm{Ru}_{2}(\mathrm{CO})_{5}(\mathrm{IAE})$ has an analogous structure, i.e. the $\mathrm{Ru}_{2}$ pair is bridged by a $10 \mathrm{e}$ IAE ligand and one $\mathrm{CO}$ group, while each $\mathrm{Ru}$ atom bears two terminal $\mathrm{CO}$ groups. The $\mathrm{Ru}$ atoms are not bonded to each other, which is as expected on basis of $18 \mathrm{e}$ for each $\mathrm{Ru}$ atom. Again it was found that the coupling is regiospecific, since for asymmetric $\mathrm{R}-\mathrm{DAB}\left\{\mathrm{H}, \mathrm{CH}_{3}\right\}$ the coupling occurs only between the two imine $\mathrm{C}$ atoms bearing a $\mathrm{H}$ atom. Further heating of $\mathrm{Ru}_{2}(\mathrm{CO})_{5}$ (IAE) and of $\mathrm{Ru}_{2}(\mathrm{CO})_{5}(\mathrm{APM})$ produces $\mathrm{Ru}_{2}(\mathrm{CO})_{4}(\mathrm{IAE})$ and $\mathrm{Ru}_{2}(\mathrm{CO})_{4}(\mathrm{APM})$, respectively. It was shown that the complexes produced do contain a $\mathrm{Ru}-\mathrm{Ru}$ bond and only terminal $\mathrm{CO}$ groups [Scheme 1]. A rather unexpected result was that further heating at higher temperatures afforded $\mathrm{Ru}_{2}(\mathrm{CO})_{4}(\mathrm{R} \cdot \mathrm{DAB})_{2}$ and $\mathrm{Ru}_{2}(\mathrm{CO})_{4}$ (R-Pyca) ${ }_{2}$, respectively. A crystal structure determination of $\mathrm{Ru}_{2}(\mathrm{CO})_{4}(\mathrm{i}-\mathrm{Pr}-\mathrm{DAB})_{2} \quad[20]$ and of $\mathrm{Ru}_{2}(\mathrm{CO})_{4}(\mathrm{R}-\mathrm{Pyca})_{2} \quad[32,33]$ shows that the R-DAB and R-Pyca groups function as 6e donor ligands positioned on oppositc sides of a $\mathrm{Ru}_{2} \mathrm{~N}_{2}$ plane [Scheme 1]. The $\mathrm{Ru} \cdot \cdots \mathrm{Ru}$ distance of $3.308(1) \AA$ in, e.g. $\operatorname{Ru}_{2}(C O)_{4}(\mathrm{i}-\mathrm{Pr}-\mathrm{DAB})_{2}$ is indicative of the absence of a metal-metal bond. It may be concluded that the $\mathrm{C}-\mathrm{C}$ bond originally formed is broken again and that $\mathrm{Ru}_{2}(\mathrm{CO})_{4}(\mathrm{R}-\mathrm{DAB})_{2}$ 
and $\mathrm{Ru}_{2}(\mathrm{CO})_{4}(\mathrm{R}-\mathrm{Pyca})_{2}$ are thermodynamically more stable than $\mathrm{Ru}_{2}(\mathrm{CO})_{4}(\mathrm{IAE})$ and $\mathrm{Ru}_{2}(\mathrm{CO})_{4}(\mathrm{APM})$, respectively $[20,32,33]$ [Scheme 1$]$.

Very interesting is the fact that reaction of $\mathrm{Ru}_{2}$ $(\mathrm{CO})_{4}$ (R-Pyca $)_{2}$ with $\mathrm{CO}$ at 1 at and at R.T. gives rise to the reformation of $\mathrm{Ru}_{2}(\mathrm{CO})_{5}(\mathrm{APM})(\mathrm{R}=$ alkyl) $[32,33]$. This $\mathrm{CO}$ promoted $\mathrm{C}-\mathrm{C}$ coupling reaction is intriguing, because in this reaction two $\mathrm{C}$-atoms situated on different metals and positioned on opposite sides of the $\mathrm{Ru}_{2} \mathrm{~N}_{2}$ plane may be brought in close proximity so that subsequent $\mathrm{C}-\mathrm{C}$. coupling occurs. It is very likely that the latter process is preceded by addition of $\mathrm{CO}$ to $\mathrm{Ru}_{2}(\mathrm{CO})_{4}(\mathrm{R}-\mathrm{Pyca})_{2}$, resulting in the formation of $\mathrm{Ru}_{2}(\mathrm{CO})_{5}(\mathrm{R}-\mathrm{Pyca})_{2}$ with one bridging $\mathrm{CO}$. In one case the back reaction occurs and this appears to be critically dependent on the type of $\alpha$-diimine, since $\mathrm{Ru}_{2}(\mathrm{CO})_{4}(\mathrm{R}-\mathrm{DAB})_{2}$ does not react with $\mathrm{CO}$ at 1 at and at R.T.

It should be noted (Scheme 1) that $\mathrm{Ru}_{2}(\mathrm{CO})_{4-}$ (R-DAB $)_{2}$ may also be formed, although in a very slow reaction, when $\mathrm{Ru}_{3}(\mathrm{CO})_{12}$ is reacted with a large excess of R-DAB ( $\mathrm{R}=\mathrm{i}-\mathrm{Pr}$, c-Hex, neo-Pe, $\mathrm{i}-\mathrm{Bu}$ ) [17]. However, in the case where $\mathrm{R}$ is aryl $\mathrm{Ru}_{2}$ $(\mathrm{CO})_{4}(\mathrm{R}-\mathrm{DAB})_{2}$ is very rapidly formed most probably also via the $\mathrm{C}-\mathrm{C}$ coupling and decoupling reactions indicated above, since the intermediate IAE complexes could be demonstrated by IR [20]. Another route for their formation via direct dimerization of $\mathrm{Ru}(\mathrm{CO})_{3}(\mathrm{R}-\mathrm{DAB})$ cannot be excluded [17].

In the first instance it was supposed that IAE formation by dimerization of two hetero-1,3butadiene ligands occurred only rarely across the periodic system. However results on compounds of $\mathrm{Mn}$ and $\mathrm{Zn}$ show that IAE type ligand formation is a widespread phenomenon.

A very recent result is the reaction of $\left[\eta^{5}-\mathrm{C}_{5}\right.$ $\left.\left.\mathrm{H}_{5}\right) \mathrm{Fe}(\mathrm{CO})_{2}\right]^{-}$with $\mathrm{MnBr}(\mathrm{CO})_{3}(\mathrm{t}-\mathrm{Bu}-\mathrm{DAB})$ which yields in addition to $\mathrm{Mn}_{2}(\mathrm{CO})_{6}(\mathrm{t}-\mathrm{Bu}-\mathrm{DAB})$, containing rather surprisingly an 8e- donor t-Bu-DAB ligand, also $\mathrm{Mn}_{2}(\mathrm{CO})_{6}$ (IAE) [24].

A crystal structure determination of $\mathrm{Mn}_{2}(\mathrm{CO})_{6}$ (IAE) $(\mathrm{R}=\mathrm{t}-\mathrm{Bu})$ shows the presence of an IAE ligand which behaves as an $8 \mathrm{e}$ donor ligand instead of a 10e donor, since one of the imine $\mathrm{N}$ atoms is not coordinating (Fig. 8; atom $\mathrm{N}(4)$ is not bonded to a metal atom). In the complex five $\mathrm{CO}$ groups are terminal bonded, while one is semibridging. In solution this $8 \mathrm{e}$ donor IAE ligand is primarily bonded to the $\mathrm{Mn}_{2}(\mathrm{CO})_{5}$ unit by the bridging amino $\mathrm{N}$-atoms. The wo imine sites take part in a fluxional motion. In this fluxional process the two imine $\mathrm{N}$ atoms $\mathrm{N}(4)$ and $\mathrm{N}(2)$ exchange intramolecularly their positions, as could be deduced from SST experiments [24]. The intermediatc may therefore contain a 6e-donor IAE ligand (analogous to the compound $\mathrm{Fe}_{2}(\mathrm{CO})_{6}$ $\left(\mathrm{PhCH}(\mathrm{Me}) \mathrm{N}=\mathrm{CHCO}_{2} \mathrm{Et}\right)_{2}$ prepared by Weiss et al.

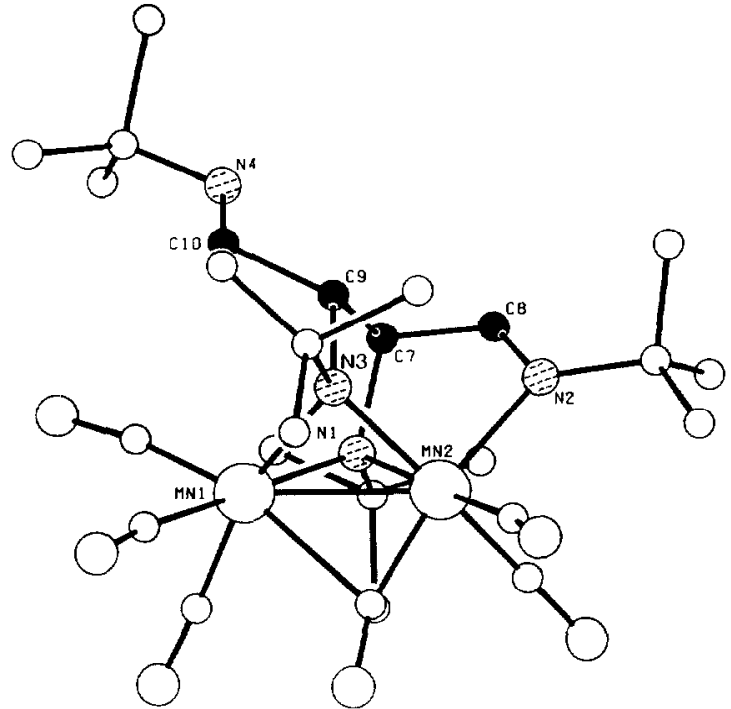

Fig. 8. Structure of $\mathrm{Mn}_{2}(\mathrm{CO})_{6}(\mathrm{IAE})$. The IAE ligand, which is formed by coupling of two t-Bu-DAB ligands, acts as an 8e-donor.

[34] (see Fig. 11)), bridging a $\mathrm{Mn}=\mathrm{Mn}$ double bond. A more likely alternative is an intermediate with a $10 \mathrm{e}$ IAE donor mode without a metal-metal bond between the two $\mathrm{Mn}$ atoms (i.e. with two electrons in the antibonding MnMn $\sigma^{*}$ molecular orbital, which should be a low lying orbital).

That the IAE ligand formation is not only restricted to transition metal compounds, but occurs also for post transition metal atoms, is shown by our $\mathrm{Zn}(\mathrm{II}) \alpha$-diimine chemistry. Reaction of $\mathrm{K}$ [t$\mathrm{Bu}-\mathrm{DAB}]$ with $\mathrm{EtZnCl}$ afforded in quantitative yield a compound of the composition [ $\mathrm{ZnEt}(\mathrm{t}$ Bu-DAB)] [31,36]. It turned out that in solution the compound exists in two forms which are in equilibrium with each other, as is shown below (Fig. 9):

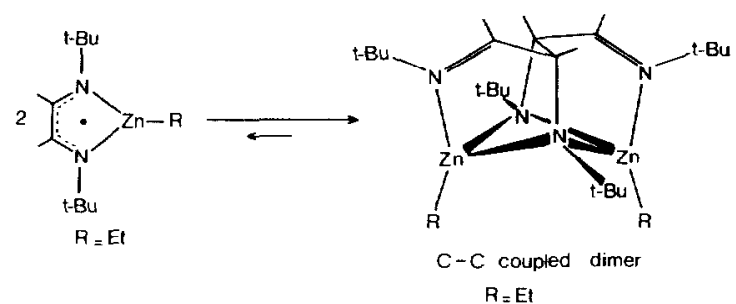

Fig. 9. Equilibrium between the radical $[\mathrm{ZnEt}(\mathrm{t}-\mathrm{Bu}-\mathrm{DAB})]^{\circ}$ and $\mathrm{Zn}_{2} \mathrm{Et}_{2}$ (IAE).

At temperatures below $-50{ }^{\circ} \mathrm{C}$ the equilibrium is completely shifted to a diamagnetic dimeric species, while at higher temperatures there is a small amount of paramagnetic monomer $[\mathrm{ZnEt}(\mathrm{t}-\mathrm{Bu}-\mathrm{DAB})]^{*}$ with $a_{\mathrm{N}} 4.87, a \mathrm{H}^{\alpha} 5.67$ (with the imine $\mathrm{N}$ and $\mathrm{H}$ ) and $a \mathrm{H}^{\beta} 0.48 \mathrm{G}$ (hyperfine splitting with the methyleneH's of the Et group) $[31,36]$. These values indicate 
delocalization of the unpaired electron, mainly on the NCCN skeleton $[31,36]$. The $\mathrm{C}-\mathrm{C}$ coupled product was also formed, but in minor amounts during the reaction of $\mathrm{ZnEt}_{2}$ with R-DAB which proceeds via $\mathrm{ZnEt}_{2}(\mathrm{R}-\mathrm{DAB})$ as an intermediate $[31,36]$. Use of $\mathrm{ZnEt}_{2}$ (R-Pyca) ${ }_{2}$ (R-Pyca $=\mathrm{C}_{5} \mathrm{H}_{4}$. $\mathrm{NC}(\mathrm{H})=\mathrm{N}-\mathrm{t}-\mathrm{Bu})$ on heating produced [EtZn(tBu-Pyca) $]^{\circ}$, which dimerises to a great extent to $[$ EtZn(t-Bu-Pyca $)]_{2}$. The crystal structure determination of this complex showed the presence of an APM type of ligand (Fig. 10) which is completely analogous to the 10e-donor IAE ligand shown in the previous reaction equilibrium [31] (Fig. 9).

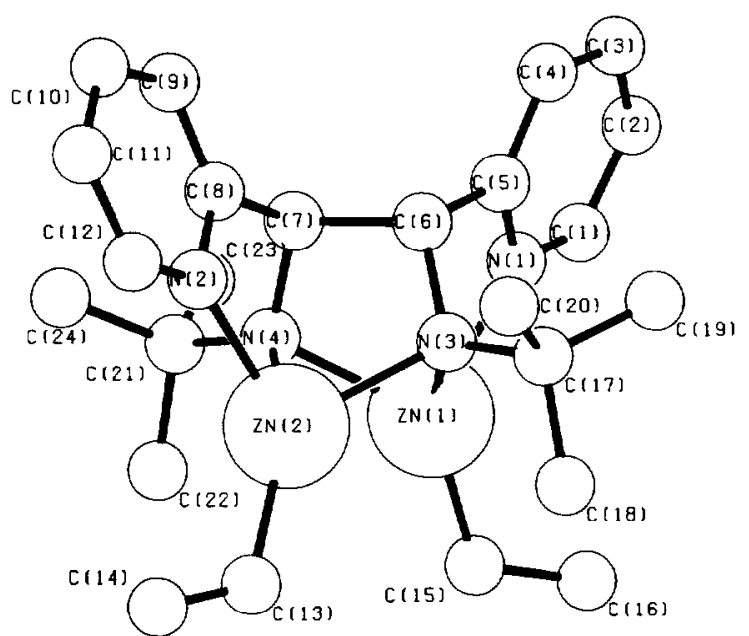

Fig. 10. Structure of $\mathrm{Zn}_{2} \mathrm{Et}_{2}$ (APM) (APM formed by coupling of two t-Bu-Pyca ligands) (see text).

In view of the available evidence on the formation of C-C coupled R-DAB and R-Pyca ligands it seems appropriate to make some remarks about the scope of these reactions and on the possible mechanisms leading to $\mathrm{C}-\mathrm{C}$ coupling between two $\alpha$-diimine groups.

When discussing the scope of the formation of IAE type ligands it is useful to consider Table III. From Table III it is clear that IAE type ligands can behave as a $10 \mathrm{e}$ - or a 8e-donor, and probably in principle also as a $6 \mathrm{e}$-donor. This is not unreasonable since in $\mathrm{Fe}_{2}(\mathrm{CO})_{6} \mathrm{~L}_{2}$ reported by Weiss et al. [34] the $\mathrm{L}_{2}$ ligand, which is formed by $\mathrm{C}-\mathrm{C}$ coupling of two $\mathrm{PhCH}(\mathrm{Me}) \mathrm{N}=\mathrm{CHCO}_{2} \mathrm{Et}$ groups (Fig. 11) donates $6 \mathrm{e}$ to the $\mathrm{Fe}_{2}(\mathrm{CO})_{6}$ moiety. If the IAE would coordinate similarly, both imine ends of the IAE ligand would be in a non-coordinating position, similar to the situation in $\mathrm{Fe}_{2}(\mathrm{CO})_{6} \mathrm{~L}_{2}$ (Fig. 11).

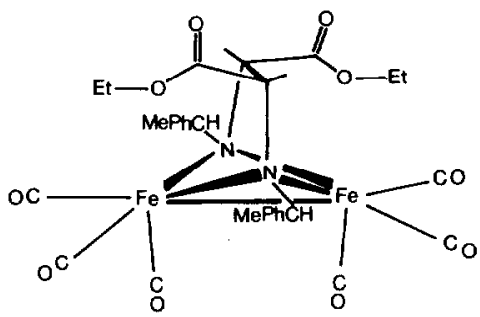

Fig. 11. Schematic structure of $\mathrm{Fe}_{2}(\mathrm{CO})_{6} \mathrm{~L}_{2}$, where $\mathrm{L}_{2}$ stands for the $\mathrm{C}-\mathrm{C}$ coupled dimer of $\mathrm{PhCH}(\mathrm{Me}) \mathrm{N}=\mathrm{CH}$ $\mathrm{CO}_{2} \mathrm{Et}$.

An intriguing aspect is that $\mathrm{Mn}_{2}(\mathrm{CO})_{6}$ (IAE) chooses a situation with a metal-metal bond and a 8e-donor IAE group instead of an arrangement with a l0e-donor IAE group without a $\mathrm{Mn}-\mathrm{Mn}$ bond. Another alternative would be $\mathrm{Mn}_{2}(\mathrm{CO})_{5}$ (IAE) with both a $\mathrm{Mn}-\mathrm{Mn}$ bond, a $10 \mathrm{e}$ donor IAE group and one bridging CO-group. Also this latter alternative would be a very plausible choice, since the structure would be analogous to $\mathrm{Ru}_{2}(\mathrm{CO})_{5}$ (IAE) in which there is no $\mathrm{Ru}-\mathrm{Ru}$ bond present. For that matter there is no reason why $\mathrm{Ru}_{2}(\mathrm{CO})_{5}$ (IAE) should not choose a situation with an $8 \mathrm{e}$ IAE ligand and $\mathrm{a} \mathrm{Ru}-\mathrm{Ru}$ bond. It may therefore be concluded that there is clearly a very delicate balance between the number of electrons donated by the IAE group and the presence or absence of metal-metal bonding.

In Table III there is still a gap for the $d^{9}$-metal complexes. However, it should be clear now that there is no reason why IAE complexes should not exist for metal atoms of the Co column.

The mechanism of the $\mathrm{C}-\mathrm{C}$ coupling reaction leading to IAE (or APM) formation is not clear for the transition metal complexes. In the case of $\mathrm{Ru}$ one might imagine a direct reaction of the R-DAB ligand with the $\eta^{2}-\mathrm{C}=\mathrm{N}$ coordinated part of the 6e-donor bonded $\mathrm{R}-\mathrm{DAB}$ group in $\mathrm{Ru}_{2}(\mathrm{CO})_{6}(\mathrm{R}-\mathrm{DAB})$

TABLE III. Complexes with IAE (APM) Type Ligands Involving C-C Coupled R-DAB (R-Pyca) Ligands, respectively.

\begin{tabular}{llllll}
\hline Electron configuration & $\mathrm{d}^{6}$ & $\mathrm{~d}^{7}$ & $\mathrm{~d}^{8}$ & $\mathrm{~d}^{9}$ & $\mathrm{~d}^{10}$ \\
\hline $\begin{array}{l}\text { Compound } \\
\begin{array}{l}\text { Number of electrons donated } \\
\text { by IAE (APM) }\end{array}\end{array}$ & $\mathrm{Mo}_{2}(\mathrm{CO})_{6}(\mathrm{IAE})^{\mathrm{d}}$ & $\mathrm{Mn}_{2}(\mathrm{CO})_{6}(\mathrm{IAE})^{\mathrm{a}}$ & $\mathrm{Ru}_{2}(\mathrm{CO})_{5}(\mathrm{APM})^{\mathrm{b}}$ & - & $\mathrm{Zn}_{2} \mathrm{Et}_{2}(\mathrm{IAE})^{\mathrm{c}}$ \\
\begin{tabular}{l}
$\mathrm{M} \cdots \mathrm{M}$ distance $(\mathrm{A})$ \\
\hline
\end{tabular} & $\mathrm{Mo}-\mathrm{Mo}=2.813(3)$ & $\mathrm{Mn}-\mathrm{Mn}=2.585(6)$ & $\mathrm{Ru} \cdots \mathrm{Ru}=2.857(2)$ & - & $\mathrm{Zn} \cdots \mathrm{Zn}=2.749(1)$ \\
\hline
\end{tabular}

${ }^{a}$ One end of the IAE ligand is not coordinated (see Fig. 8). $\quad b_{R}=$ i-Pr. $\quad c_{R}=t-B u$ (see Fig. 10). $\quad$ d See Fig. 7. 
[20]. As indicated in Scheme 1 it seems more likely that $\mathrm{Ru}_{2}(\mathrm{CO})_{5}(\mathrm{R}-\mathrm{DAB})$ with R-DAB in the 8edonor mode is formed first, after which the incoming R-DAB may be easily $\sigma-\mathrm{N}$ attached to the reactive pentacarbonyl complex. The coordinated R-DAB moves to the 6e-donor mode, after which the noncoordinated end of the second R-DAB group is inserted into the metal $-\eta^{2}-\mathrm{C}=\mathrm{N}$ bond.

There is a possibility that radical reactions or S.E.T. reactions are also involved. Such reactions should not be excluded, since for $\mathrm{Zn}[31,35]$ (and possibly Mo) radicals play a role [30].

In order to obtain more insight about the reaction pathway taking place reactions have been studied of $\mathrm{Ru}_{2}(\mathrm{CO})_{\mathrm{n}}(\mathrm{R}-\mathrm{DAB})(\mathrm{n}=5,6)$ with ligands such as $\mathrm{RN}=\mathrm{C}=\mathrm{NR}, \mathrm{R}_{2} \mathrm{C}=\mathrm{S}=\mathrm{O}$ and $\mathrm{R}-\mathrm{C} \equiv \mathrm{CR}^{\prime}$.

\section{Coupling of R-DAB Ligand with $R N=C=N R$ and $\mathrm{R}_{2} \mathrm{C}=\mathrm{S}=\mathbf{O}$}

In the case of the reaction of $\mathrm{Ru}_{2}(\mathrm{CO})_{6}(\mathrm{t}-\mathrm{Bu}$ DAB) with $\mathrm{R}^{\prime} \mathrm{N}=\mathrm{C}=\mathrm{NR}^{\prime}$ ( $\mathrm{R}^{\prime}=\mathrm{p}-\mathrm{Tol}$, $\left.\mathrm{i}-\mathrm{Pr}, \mathrm{c}-\mathrm{Hex}\right)$ the main product was $\mathrm{Ru}_{2}(\mathrm{CO})_{5}$ (AIP) ( $\mathrm{AIP}\{\mathrm{t}-\mathrm{Bu}$, $\mathrm{R}^{\prime}$ \} is 1,2-diamino-2,3-diimino-propane) [36]. The crystal structure of $\mathrm{Ru}_{2}(\mathrm{CO})_{5}\{(\mathrm{t}-\mathrm{BuN}=\mathrm{CHC}(\mathrm{H})$ $(\mathrm{N}-\mathrm{t}-\mathrm{Bu}) \mathrm{C}(\mathrm{N}-\mathrm{p}-\mathrm{Tol})=\mathrm{N}-\mathrm{p}-\mathrm{Tol})\}$ shows the presence of one bridging $\mathrm{CO}$ group and further two terminal $\mathrm{CO}$ groups on each $\mathrm{Ru}$ atom. The $\mathrm{Ru}-\mathrm{Ru}$ bond length is $2.78 \AA$, which is fairly long since single bond lengths for $\mathrm{Ru}$ are generally found between 2.70 and $2.75 \AA$. The t-Bu-DAB ligand is coupled to the carbodiimide via a $\mathrm{C}-\mathrm{C}$ bond of $1.53 \AA$. One $\mathrm{N}$ atom of the carbodiimide ligand is bridging the two $\mathrm{Ru}$ atoms, while the other $\mathrm{N}$ atom is not coordinated. (Fig. 12).

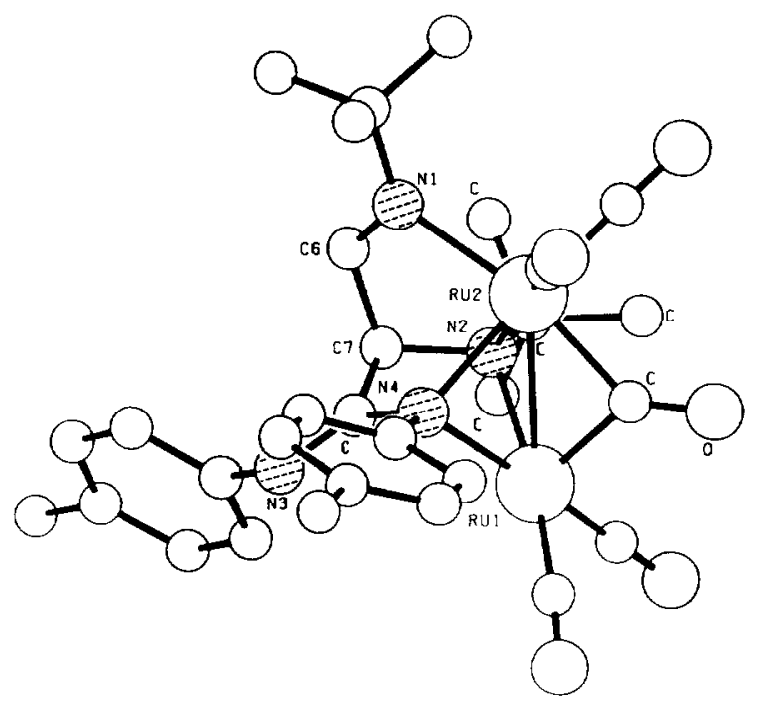

Fig. 12. The molecular geometry of $\mathrm{Ru}_{2}(\mathrm{CO})_{5}(\mathrm{AIB}\{\mathrm{t}-\mathrm{Bu}, \mathrm{p}$ Tol $\}$ ) where $A I B$ is formed by $C-C$ coupling of t-Bu-DAB with p-TolN $=\mathrm{C}=\mathrm{N}-\mathrm{p}$-Tol.
The non-coordinated $\mathrm{C}=\mathrm{N}$ bond is $1.40 \AA$, as would be expected.

Reactions of $\mathrm{Ru}_{2}(\mathrm{CO})_{6}(\mathrm{R}-\mathrm{DAB})(\mathrm{R}=\mathrm{i}-\mathrm{Pr}, \mathrm{t}-\mathrm{Bu}$, c-Hex) with thiofluorenone-S-oxide $\left(\mathrm{C}_{12} \mathrm{H}_{8} \mathrm{C}=\mathrm{S}=\mathrm{O}\right)$ afforded as the main product $\mathrm{Ru}_{2}(\mathrm{CO})_{5}\left(\mathrm{C}_{12} \mathrm{H}_{8} \mathrm{C}=\mathrm{S}\right)$ (t-Bu-DAB) and carbon dioxide [36]. The crystal structure determination of $\mathrm{Ru}_{2}(\mathrm{CO})_{5}\{(\mathrm{i}-\mathrm{PrN}=\mathrm{CHC}$. (H) $\left.[\mathrm{N}(\mathrm{i}-\mathrm{Pr})] \mathrm{C}(\mathrm{S}) \mathrm{C}_{12} \mathrm{H}_{8}\right\}$ shows again the characteristic $\mathrm{Ru}_{2}(\mathrm{CO})_{5}$ unit with four terminal and one bridging $\mathrm{CO}$ group. The i-Pr-DAB ligand is coupled via a $\mathrm{C}-\mathrm{C}$ bond $\left(1.61 \AA\right.$ (mean)) to the $\mathrm{C}_{12} \mathrm{H}_{8} \mathrm{C}=\mathrm{S}$ moiety. The S-atom bridges asymmetrically both $\mathrm{Ru}$ atoms, while the $\mathrm{C}=\mathrm{S}$ bond is formally reduced to a single $\mathrm{C}-\mathrm{S}$ bond $(1.91(2) \AA$ ) (Fig. 13).

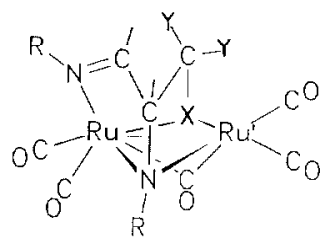

Fig. 13. The schematic structure of $\mathrm{Ru}_{2}(\mathrm{CO})_{5}\{\mathrm{i}-\mathrm{Pr}-\mathrm{N}=$ $\left.\mathrm{CHC}(\mathrm{H})[\mathrm{N}(\mathrm{i}-\mathrm{Pr})] \mathrm{C}(\mathrm{S}) \mathrm{C}_{12} \mathrm{H}_{8}\right\}$. The ligand is formed by $\mathrm{C}-\mathrm{C}$ coupling of $\mathrm{i}-\mathrm{Pr}-\mathrm{DAB}$ with a thioketone $\mathrm{C}_{12} \mathrm{H}_{8} \mathrm{C}=\mathrm{S}$ moiety.

It is of interest to point out that it is clearly possible to couple $\mathrm{C}$ atoms even when the $\mathrm{C}$ atom of the incoming ligand contains groups other than $\mathrm{H}$, i.e. a $\mathrm{RN}=$ grouping or two $\mathrm{R}$ groups as in the deoxygenated sulfine.

A second point of interest is the reaction route leading to the $\mathrm{C}-\mathrm{C}$ coupled products. In the case of the reactions with $\mathrm{R}_{2} \mathrm{C}=\mathrm{S}=\mathrm{O}$ and $\mathrm{RN}=\mathrm{C}=\mathrm{NR}$ it turns out that if $\mathrm{Ru}_{2}(\mathrm{CO})_{5}(\mathrm{R}-\mathrm{DAB})$ is used the reaction with $\mathrm{R}_{2} \mathrm{C}=\mathrm{S}=\mathrm{O}$ only gives decomposition products, while reaction with $\mathrm{RN}=\mathrm{C}=\mathrm{NR}$ gave very small yields of the $C \mathrm{C}$ coupled product [36]. These observations appear to indicate that a direct reaction of $\mathrm{Ru}_{2}(\mathrm{CO})_{6}(\mathrm{R}-\mathrm{DAB})$, and not of $\mathrm{Ru}_{2}$. $(\mathrm{CO})_{5}(\mathrm{R}-\mathrm{DAB})$, with $\mathrm{R}_{2} \mathrm{C}=\mathrm{S}=\mathrm{O}$ and $\mathrm{RN}=\mathrm{C}=\mathrm{NR}$ is necessary. One is therefore led to believe that an insertion reaction occurs via a concerted mechanism. In addition a concurrent reaction takes place which involves direct substitution of coordinated R.DAB by $\mathrm{R}_{2} \mathrm{C}=\mathrm{S}=\mathrm{O}$ or $\mathrm{RN}=\mathrm{C}=\mathrm{NR}$ yielding free R-DAB, which then reacts with unreacted $\mathrm{Ru}_{2}(\mathrm{CO})_{6}$ (R-DAB) to afford $\mathrm{Ku}_{2}(\mathrm{CO})_{\mathrm{n}}(\mathrm{IAE})(\mathrm{n}=5,4)$ (Scheme 1). It should be noted in support of this, that heating of $\mathrm{Ru}_{2}(\mathrm{CO})_{6}(\mathrm{R}-\mathrm{DAB})$ on its own did not lead to formation of $\mathrm{Ru}_{2}(\mathrm{CO})_{\mathrm{n}}(\mathrm{IAE})$ [36].

With regards to the intimate reaction steps one can argue that owing to $\pi$-backbonding to the $\eta^{2}$. $\mathrm{C}=\mathrm{N}$ bonded moiety the $\mathrm{C}$ atom gains negative charge more than $\mathrm{N}$ does, since $\mathrm{N}$ donates electrons via $\sigma$-bonding to two $\mathrm{Ru}$-atoms. As a result $\mathrm{C}$ becomes more negative than does $\mathrm{N}$. In the case of reactions with $\mathrm{RN}=\mathrm{C}=\mathrm{NR}$, attack of the positively 
polarized $\mathrm{C}$ atom (pseudo allenic $\mathrm{C}$ centre) in the latter ligand with the negatively polarized $\eta^{2}-C=N$ bonded $\mathrm{C}$ atom of the R-DAB ligand may then occur. In the case of the reaction with sulfine the situation is more complicated, but it is not unreasonable to assume that the negatively charged $\mathrm{O}$-atom attacks the positively polarized $\mathrm{C}$ atom of a carbonyl group producing $\mathrm{CO}_{2}$ together with a thioketone function with a positively polarized $\mathrm{C}$ atom, which then undergoes $\mathrm{C}-\mathrm{C}$ coupling with the $\eta^{2}-\mathrm{C}=\mathrm{N}$ unit. [N.B. Floriani et al. $[37,38]$ noted that Goup VIII metal atoms in low oxidation states generally gave $\mathrm{C}-\mathrm{X}$ coupling in reactions with $\mathrm{C}=\mathrm{X}$ functional groups, which must therefore be explained by a different mechanism.]

When we now consider again the reaction of $\mathrm{R}-\mathrm{DAB}$ with $\mathrm{Ru}_{2}(\mathrm{CO})_{5}(\mathrm{R}-\mathrm{DAB})$ such a polar mechanism may also occur, but clearly $\mathrm{N}$-coordination must first take place at one side of the $\mathrm{N}=\mathrm{C}-\mathrm{C}=\mathrm{N}$ skeleton followed by a polar $\mathrm{C}=\mathrm{N}$ addition of the other (still uncoordinated) side of the R-DAB skeleton to the polarized $\eta^{2}-\mathrm{C}=\mathrm{N}$ bond.

\section{E. Catalytic C-C Coupling Reactions Involving $\mathbf{R u}_{\mathbf{2}^{-}}$ $(\mathrm{CO})_{\mathbf{n}}(\mathrm{R}-\mathrm{DAB})(\mathrm{n}=5,6)$}

Reactions of $\mathrm{Ru}_{2}(\mathrm{CO})_{6}(\mathrm{R}-\mathrm{DAB})(\mathrm{R}=\mathrm{i} \cdot \mathrm{Pr}, \mathrm{t}-\mathrm{Bu}$, c-Hex) with acetylene and with mono- and disubstituted alkynes $\left(\mathrm{R}^{\prime}=\mathrm{R}^{\prime \prime}=\mathrm{CH}_{3} \mathrm{O}_{2} \mathrm{C}, \mathrm{CD}_{3} \mathrm{O}_{2} \mathrm{C}\right.$-; $\mathbf{R}^{\prime}=\mathrm{R}^{\prime \prime}=\mathrm{H}: \mathbf{R}^{\prime}=\mathrm{H}, \mathbf{R}^{\prime \prime}=\mathrm{CH}_{3} \mathrm{O}_{2} \mathrm{C}-$, Ph, p-Tol, t-Bu) involves a sequence of steps (see Scheme 2) [39]. The first step involves insertion of $R^{\prime} C \equiv C R^{\prime \prime}$ with formation of $\mathrm{Ru}_{2}(\mathrm{CO})_{5}$ (AIB) (AIB is 3-amino4-imino-1-butene-1-yl). The crystal structure determination of $\mathrm{Ru}_{2}(\mathrm{CO})_{5}\left[(\mathrm{t}-\mathrm{Bu}-\mathrm{DAB})\left(\mathrm{PhC}_{2} \mathrm{H}\right)\right]$ shows that the alkyne is coupled via the $-\mathrm{CPh}$ end (and thus not via the - $\mathrm{CH}$ end) of the alkyne to the $\mathrm{C}$ atom of the t-Bu-DAB ligand. The $\mathrm{C}-\mathrm{C}$ bond formed between the t-Bu-DAB ligand and - $\mathrm{CPh}$ end of the alkyne is $1.546(10) \AA$ long. In the $\mathrm{Ru}_{2}(\mathrm{CO})_{5}$ moiety there are two terminal $\mathrm{CO}$ ligands per $\mathrm{Ru}$ atom and one $\mathrm{CO}$ group bridging the $\mathrm{Ru}-\mathrm{Ru}$ bond of 2.711(1) $\AA$. The original acetylenic triple bond is reduced to a double $\mathrm{C}=\mathrm{C}$ bond of $1.346(10) \AA$. The fact that the $\mathrm{CPh}$ end of the alkyne is coupled to t-Bu-DAB and not the $-\mathrm{CH}$ side again demonstrates that there is a delicate balance between steric and electronic influences which determines the pathway of the $\mathrm{C}-\mathrm{C}$ coupling reaction. Close inspection of the structure of $\mathrm{Ru}_{2}(\mathrm{CO})_{5}\left[(\mathrm{t}-\mathrm{Bu}-\mathrm{DAB})\left(\mathrm{PhC}_{2} \mathrm{H}\right)\right]$ shows that the complex has one electron-deficient Ru-centre, if one assumes that the $\mathrm{C}=\mathrm{C}$ double bond is not or only slightly coordinating to one of the $\mathrm{Ru}$ atoms. This assumption is reasonable, since the $\mathrm{C}=\mathrm{C}$ bond length, as has been pointed out above, is characteristic for a double bond. Consequently it is possible to add a second molecule of alkyne to produce $\mathrm{Ru}_{2}(\mathrm{CO})_{5}$ $\left\{(\mathrm{t}-\mathrm{Bu}-\mathrm{DAB})\left(\mathrm{PhC}_{2} \mathrm{H}\right)(\right.$ alkyne) $\}$ (Scheme 2$)$ in which

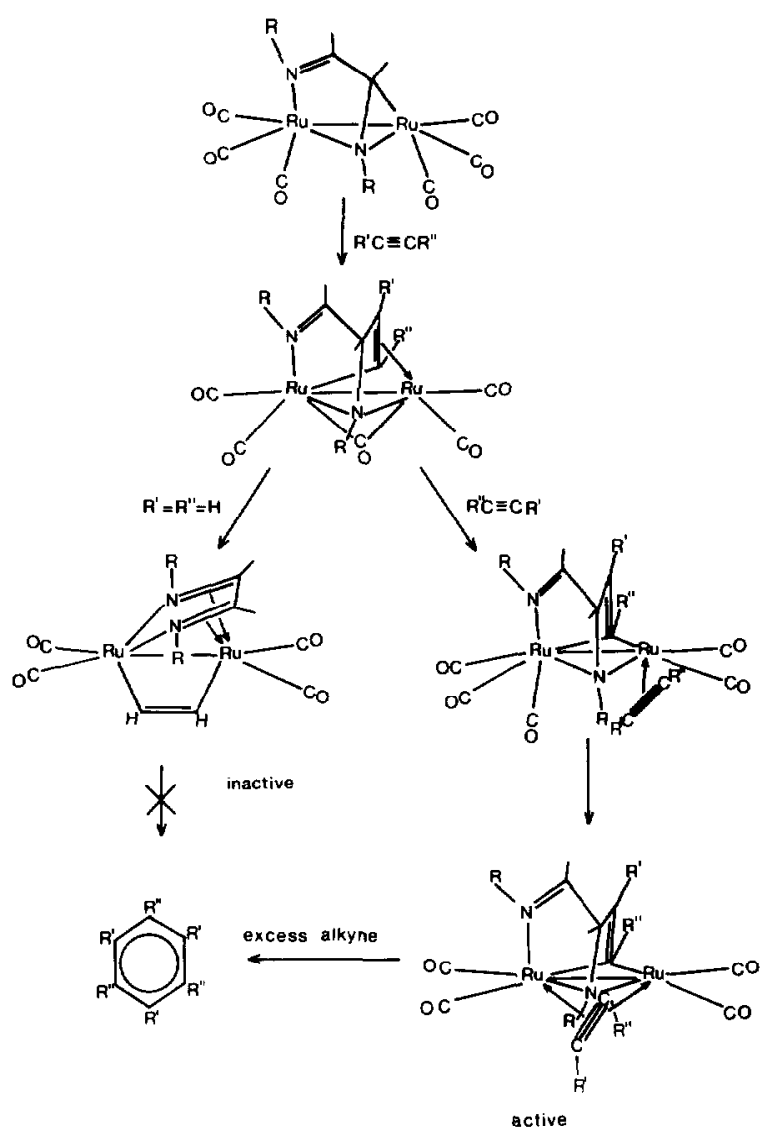

Scheme 2. Reaction of $\mathrm{Ru}_{2}(\mathrm{CO})_{6}(\mathrm{R}-\mathrm{DAB})$ with alkynes.

the alkyne must behave as a $2 \mathrm{e}$ donor. In this complex all five $\mathrm{CO}$ groups are terminally bonded. Further heating of this complex afforded $\mathrm{Ru}_{2}(\mathrm{CO})_{4}$ $\left\{(\mathrm{t}-\mathrm{Bu}-\mathrm{DAB})\left(\mathrm{PhC}_{2} \mathrm{H}\right)\right\}$ (alkyne) which contains a $4 \mathrm{e}$ donor alkyne bridging the $\mathrm{Ru}_{2}$ pair. Finally, reaction with excess alkyne led to the catalytic formation of substituted benzenes, of which the monosubstituted alkynes only gave 1,3,5-trisubstituted benzenes. This high selectivity is unusual since catalysts were reported to give mixtures of various substituted benzene products [40-42].

The reaction with acetylene, $\mathrm{HC} \equiv \mathrm{CH}$, is exceptional since no catalytic reaction was observed, but instead only the formation of $\mathrm{Ru}_{2}(\mathrm{CO})_{4}(\mu$ $\mathrm{HC}_{2} \mathrm{H}$ )(R-DAB) (Scheme 2 and Fig. 1) from $\mathrm{Ru}_{2}$ (CO) ${ }_{5}$ (AIB). We see here another example that the $\mathrm{C}-\mathrm{C}$ bond formation is also ruptured again. The crystal structure determination of $\mathrm{Ru}_{2}(\mathrm{CO})_{4}(\mu$ $\left.\mathrm{HC}_{2} \mathrm{H}\right)(\mathrm{i}-\mathrm{Pr}-\mathrm{DAB})$ showed an 8e i-Pr-DAB donor group bridging a $\mathrm{Ru}-\mathrm{Ru}$ bond of $2.936(1) \AA$. The $\mathrm{Ru}-\mathrm{Ru}$ bond is further bridged by the acetylene molecule which lies parallel to the $R \mathbf{R}-\mathbf{R u}$ axis (Fig. 1, Scheme 2). 


\section{F. Conversion of the Neutral R-DAB Ligands into Mono-anionic 3-Amino-1-azaallyl Ligands}

A very interesting reaction of $\mathrm{Ru}_{2}(\mathrm{CO})_{6}(\mathrm{R}$-DAB) ( $\mathrm{R}=\mathrm{i}-\mathrm{Pr}, \mathrm{c} \cdot \mathrm{Hex}$; but not $\mathrm{t}-\mathrm{Bu}$ ) with ketene $\mathrm{H}_{2} \mathrm{C}=\mathrm{C}=$ $\mathrm{O}$ did not yield the expected $\mathrm{C}-\mathrm{C}$ coupled product in analogy to the reaction with $\mathrm{RN}=\mathrm{C}=\mathrm{NR}$ (vide infra), but instead in virtually guantitative yields a compound $\mathrm{Ru}_{2}(\mathrm{CO})_{5}[\mathrm{i}-\operatorname{Pr} \overline{\mathrm{N}} \overline{\mathrm{C}}(\overline{\mathrm{H}}) \overline{\mathrm{C}}(\mathrm{H}) \mathrm{N}(\mathrm{i}-\mathrm{Pr}) \mathrm{C}(\mathrm{O})$ $\left.\overline{\mathrm{CH}}_{2} \mathrm{C}(\mathrm{O}) \mathrm{CH}_{2}\right]$ in which $\mathrm{N}-\mathrm{C}$ coupling has occurred [43]. A crystal structure determination of this compound (Fig. 14) showed that the framework consists of a $\mathrm{Ru}_{2}(\mathrm{CO})_{5}$ moiety $(\mathrm{Ru}-\mathrm{Ru}=2.752(1)$ $\AA)$ with all $\mathrm{CO}$ groups terminally bonded. The $\mathrm{Ru}-$

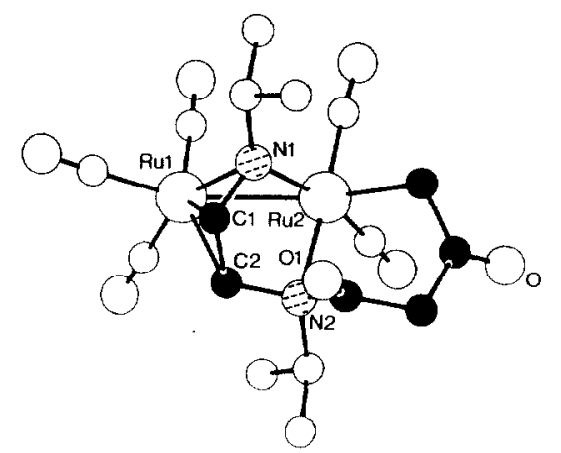

Fig. 14. Molecular structure of $\operatorname{Ru}_{2}(\mathrm{CO})_{5}[\mathrm{i}-\mathrm{Pr}-\overline{\mathrm{N}} \overline{\overline{\mathrm{C}}}(\overline{\mathrm{H}}) \overline{\mathrm{C}} \mathrm{HN}(\mathrm{i}-$ $\mathrm{Pr}) \mathrm{C}(\mathrm{O}) \mathrm{CH}_{2} \mathrm{C}(\mathrm{O}) \mathrm{CH}_{2}$ formed from $\mathrm{Ru}_{2}(\mathrm{CO})_{6}(\mathrm{i}-\mathrm{Pr}-\mathrm{DAB})$ and ketene.

$\mathrm{Ru}$ bond is spanned by a $8 \mathrm{e}$-donor terdentate ligand which is formed via N-C coupling of the coordinated 6e-donor i-Pr-DAB ligand in $\mathrm{Ru}_{2}(\mathrm{CO})_{6}(\mathrm{R}-\mathrm{DAB})$ to a non-cyclic diketene group. One finds that the RNCC unit in the DAB skeleton is $\eta^{3}$-azaallyl coordinated to $\mathrm{Ru}(1)$ with $\mathrm{N}(1)-\mathrm{C}(1)$ and $\mathrm{C}(1)-\mathrm{C}(2)$ bond lengths of $1.396(7)$ and $1.405(8) \AA$, respectively. The other part of the ligand is a sixmembered $\mathrm{RuCH}_{2} \mathrm{C}(\mathrm{O}) \mathrm{CH}_{2} \mathrm{C}(\mathrm{O}) \mathrm{N}(\mathrm{i}-\mathrm{Pr})$ ring composed of a head-to-tail coupled diketene group. The reaction mechanism leading to this product is unknown. Reaction of diketene (head-to-head and tail-to-tail dimer of ketene) does not give this product when reacted with $\mathrm{Ru}_{2}(\mathrm{CO})_{6}(\mathrm{R}-\mathrm{DAB})$ [43].

\section{G. Cation-Anion Reactions Involving R-DAB Metal Compounds}

In this section we discuss separately reactions of $\mathrm{MX}(\mathrm{CO})_{3}(\mathrm{R}-\mathrm{DAB})(\mathrm{M}=\mathrm{Mn}, \mathrm{Re} ; \mathrm{X}=$ halide $)$ with a number of metal anions. The aim of this study was to investigate the coordination chemistry of R-DAB bonded to heterobinuclear metal pairs. There is a large variety of reactions which have led to novel type of coordination modes and activation of the coordinated R-DAB ligand.

\section{Reaction of $\mathrm{MX}(\mathrm{CO})_{3}(\mathrm{R}-\mathrm{DAB})$ with $\left(\mathrm{Mn}(\mathrm{CO})_{5}\right]^{-}$} $(M=M n, R e)$

The halide $\mathrm{X}^{-}$in $\mathrm{MX}(\mathrm{CO})_{3}(\mathrm{R}-\mathrm{DAB})(\mathrm{M}=\mathrm{Mn}$, Re; $\left.\mathrm{X}=\mathrm{Cl}, \mathrm{Br}, \mathrm{I} ; \mathrm{R}=\mathrm{i}-\mathrm{Pr}, \mathrm{di}-\mathrm{iPr} \mathrm{r}_{2}-\mathrm{Me}, \mathrm{p}-\mathrm{Tol}\right)$ may be substituted by $\left[\mathrm{Mn}(\mathrm{CO})_{5}\right]^{-}$to give in about $80 \%$ yields the complexes $(\mathrm{CO})_{5} \mathrm{MnM}(\mathrm{CO})_{3}(\mathrm{R}$ DAB) [44]. The large yields indicate a straightforward nucleophilic substitution mechanism. ${ }^{1} \mathrm{H}$ and ${ }^{13} \mathrm{C}$ NMR indicate that the R-DAB remains chelating to the metal $\mathrm{M}$. Further heating or applying light to these binuclear complexes did not result in further reactions [42].

\section{Reaction of $\mathrm{MBr}(\mathrm{CO})_{3}(\mathrm{R}-\mathrm{DAB})$ with $\mathrm{Co}(\mathrm{CO})_{4}{ }^{-}$}

The first step of this high yield reaction is analogous to the previous one, since substitution of $\mathrm{Br}^{-}$in $\mathrm{MBr}(\mathrm{CO})_{3}(\mathrm{R}-\mathrm{DAB})(\mathrm{M}=\mathrm{Mn}, \mathrm{Re} ; \mathrm{R}=\mathrm{i}-\mathrm{Pr}$, $\mathrm{t}-\mathrm{Bu}$, c-Hex) by $\left[\mathrm{Co}(\mathrm{CO})_{4}\right]^{-}$produced first the unstable (CO) $)_{4} \mathrm{CoM}(\mathrm{CO})_{3}$ (R-DAB) [45] (Fig. 15).

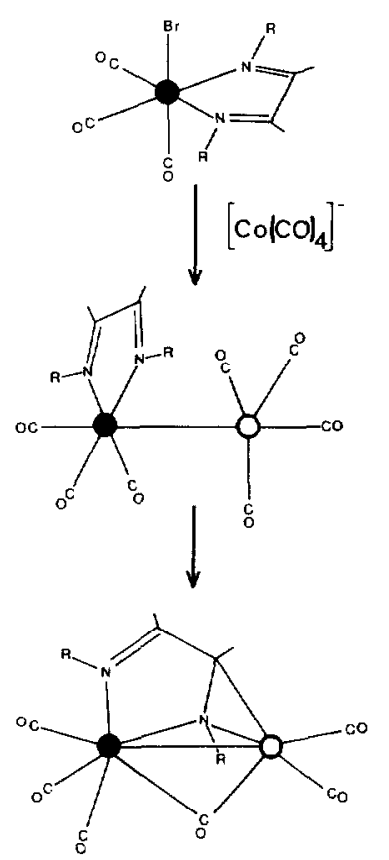

Fig. 15. Proposed reaction pathway for the formation of $\mathrm{MnCo}(\mathrm{CO})_{6}(\mathrm{R}-\mathrm{DAB})$

Subsequently one $\mathrm{CO}$ molecule was lost by an intramolecular substitution of one $\mathrm{CO}$ on $\mathrm{Co}$ by a $\mathrm{C}=\mathrm{N}$ bond of the R-DAB ligand, which as a result becomes $\eta^{2}$-bonded to $\mathrm{Co}$. The crystal structure determination of $\mathrm{MnCo}(\mathrm{CO})_{6}(\mathrm{t}-\mathrm{Bu}-\mathrm{DAB})$ shows a $\mathrm{MM}^{\prime}(\mathrm{CO})_{6}$ unit bridged by a 6e-R-DAB group with one of the imine units $\eta^{2}$-bonded to $\mathrm{Co}$. The $\mathrm{Mn}-\mathrm{Co}$ bond is 2.639(3) $\AA$ [45]. The $\sigma$-bonded $\mathrm{N}=\mathrm{C}$ bond is $1.26(1) \AA$ and the $\eta^{2}-\mathrm{N}=\mathrm{C}$ unit is $1.36(1) \AA$. The complex contains five terminal CO groups and one 
semibridging $\mathrm{CO}$ group. The $\mathrm{Mn}-\mathrm{CO}$ (bridging) and $\mathrm{Co}-\mathrm{CO}$ (bridging) bond distances are $2.33(1)$ $\AA$ and $1.80(1) \AA$, respectively. From ${ }^{13} \mathrm{C}$ NMR on the carbonyl groups it can be deduced that the two terminal $\mathrm{CO}$ groups on $\mathrm{Co}$ and the semibridging carbonyl group are exchanging on the NMR time scale while the terminal $\mathrm{CO}$ groups on $\mathrm{Mn}$ remain rigid. Another fluxional process was observed for $\mathrm{MnCo}(\mathrm{CO})_{6}(\mathrm{i}-\mathrm{Pr}-\mathrm{DAB}\{\mathrm{Me}, \mathrm{Me}\})$ in which the $\sigma-\mathrm{N}=\mathrm{C}$ and $\eta^{2}$-bonded $\mathrm{C}=\mathrm{N}$ groups exchange intramolecularly their positions on the NMR time scale. This process only occurs for this Me substituted R-DAB group, and has not been found for 6e-R-DAB groups with $\mathrm{H}$ atoms on the imine $\mathrm{C}$ atoms. Clearly the Me groups on the imine $\mathrm{C}$-atoms have a destabilizing influence on the bond strength of the metal- $\eta^{2}-\mathrm{N}=\mathrm{C}$ bond [45].

3. Reaction of $\left[\mathrm{Mo}(\mathrm{CO})_{4}(\mathrm{R}-\mathrm{DAB})\right]^{-}$with either $\mathrm{MnBr}(\mathrm{CO})_{5}$ or $\mathrm{MBr}(\mathrm{CO})_{3}(\mathrm{R}-\mathrm{DAB})$

The reaction of $\mathrm{MBr}(\mathrm{CO})_{3}(\mathrm{R}-\mathrm{DAB})(\mathrm{M}=\mathrm{Mn}, \mathrm{Re})$ or of $\operatorname{MnBr}(\mathrm{CO})_{5}$ with $\left[\mathrm{Mo}(\mathrm{CO})_{4}(\mathrm{R}-\mathrm{DAB})\right]^{-}$has been discussed previously. The product is $\mathrm{Mo}_{2}$ $(\mathrm{CO})_{6}$ (IAE) (see Fig. 7) [30].

\section{Reaction of $\operatorname{MnBr}(C O)_{3}(t-B u-D A B)$ with $\left[\left(\eta^{5}\right.\right.$ - $\left.\left.\mathrm{C}_{5} \mathrm{H}_{5}\right) \mathrm{Fe}(\mathrm{CO})_{2}\right]^{-}$}

In a previous Section it has already been mentioned that reaction of $\mathrm{MnBr}(\mathrm{CO})_{3}(\mathrm{t}-\mathrm{Bu}-\mathrm{DAB})$ with $\left[\left(\eta^{5}-\mathrm{C}_{5} \mathrm{H}_{5}\right) \mathrm{Fe}(\mathrm{CO})_{2}\right]^{-}$afforded two products, one of which being $\mathrm{Mn}_{2}(\mathrm{CO})_{6}$ (IAE) (Fig. 8) and the other $\mathrm{Mn}_{2}(\mathrm{CO})_{6}(\mathrm{t}-\mathrm{Bu}-\mathrm{DAB})$ [24]. This type of reaction is strongly reminiscent of the previous one in which $\mathrm{Mo}_{2}(\mathrm{CO})_{6}$ (IAE) was formed, however, as the only product. Analogous to the reaction discussed before the anion is needed to start the reaction.

The structure of $\mathrm{Mn}_{2}(\mathrm{CO})_{6}$ (IAE) has been discussed before, while $\mathrm{Mn}_{2}(\mathrm{CO})_{6}(\mathrm{t}-\mathrm{Bu}-\mathrm{DAB})$ has probably a structure analogous to $\mathrm{Mn}_{2}(\mathrm{CO})_{6}$ (Me-DAB $\{\mathrm{Me} ; \mathrm{Me}\})$ [12].

\section{Reaction of $\mathrm{MBr}(\mathrm{CO})_{3}(\mathrm{R}-\mathrm{DAB})(M=\mathrm{Mn}, \mathrm{Re})$ with $\left[\mathrm{HFe}(\mathrm{CO})_{4}\right]^{-}$}

Intriguing reactions have been observed between $\mathrm{MBr}(\mathrm{CO})_{3}$ (R-DAB) with the anion $\left[\mathrm{HFe}(\mathrm{CO})_{4}\right]^{-}$. The type of reaction is greatly dependent on the type of $\alpha$-diimine, the $R$ group and on $M(\mathrm{Mn}, \mathrm{Re})$ [46].

It was found that $\operatorname{MBr}(\mathrm{CO})_{3}(\mathrm{t}-\mathrm{Bu}-\mathrm{DAB})(\mathrm{M}=$ $\mathrm{Mn}, \mathrm{Re}$ ) reacted with $\left[\mathrm{HFe}(\mathrm{CO})_{4}\right]^{-}$to give $\mathrm{FeM}$ $(\mathrm{CO})_{6}(\mathrm{t}-\mathrm{Bu}-\mathrm{AAA})$ where t-Bu-AAA stands for 3-tertiarybutylamino-1-tertiarybutyl-1-azaallyl. The crystal structure determination of this compound (Fig. 16) shows that it consists of a $(\mathrm{CO})_{3} \mathrm{FeMn}(\mathrm{CO})_{3}$ unit with a rather short $\mathrm{Fe}-\mathrm{Mn}$ bond of 2.628(4) $\AA$ (average). Five $\mathrm{CO}$ groups are terminally bonded, three to $\mathrm{Mn}$ and two to $\mathrm{Fe}$. The bridging $\mathrm{CO}$ group

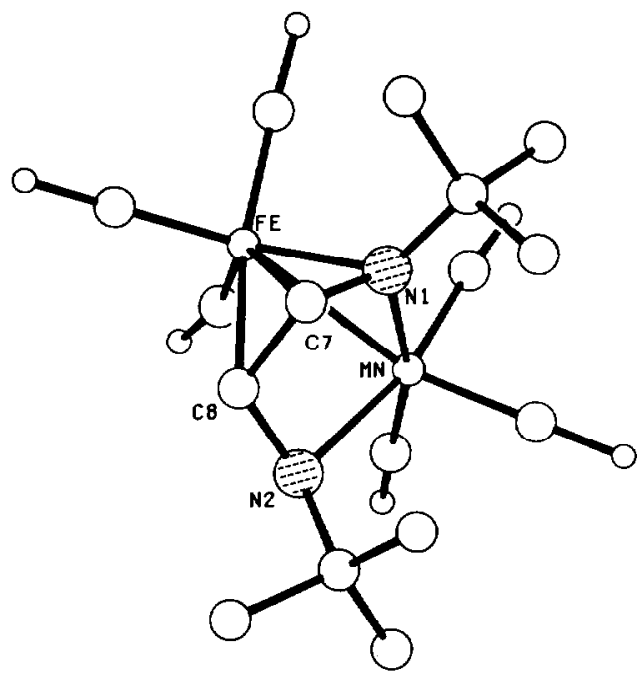

Fig. 16. The molecular geometry of $\mathrm{FeMn}(\mathrm{CO})_{6}(\mathrm{t}-\mathrm{Bu}-\mathrm{AAA})$ (see text).

is a semibridging one, as shown by the large difference in metal-carbon bond lengths $(\mathrm{Fe}-\mathrm{C}=1.72$ $\AA$ (mean) and $\mathrm{Mn}-\mathrm{C}=2.59 \AA$ (mean), as well as the large difference in bond angles $(\mathrm{Fe}-\mathrm{C}-\mathrm{O}=$ $167.3^{\circ}$ (mean) and $\mathrm{Mn}-\mathrm{C}-\mathrm{O}=120.6^{\circ}$ (mean)). The bond lengths within the metal-t-Bu-AAA fragment indicate that the AAA unit donates $4 \mathrm{e}$ $\left(\sigma-\mathrm{N}, \sigma-\mathrm{N}^{\prime}\right)$ to $\mathrm{Mn}$ and also $4 \mathrm{e}$ via an $\eta^{3}$-azaallylic anion towards $\mathrm{Fe}$. The azaallylic part is $\eta^{3}$-bonded to $\mathrm{Fe}$ with similar bond distances i.e. $\mathrm{Fe}-\mathrm{N}(1)$ $=2.04 \AA$ (mean), $\mathrm{Fe}-\mathrm{C}(7)=2.01 \AA$ (mean), $\mathrm{Fe}-\mathrm{C}(8)$ $=2.06 \AA$ (mean). The $\mathrm{N}(1)-\mathrm{C}(7)$ and $\mathrm{C}(7)-\mathrm{C}(8)$ bond lengths of $1.38 \AA$ each are also indicative of $\eta^{3}$-azaallyl bonding since they are in between single $\mathrm{N}-\mathrm{C}$ and double $\mathrm{N}=\mathrm{C}$ bond distance values. It should further be realized that such an $\eta^{3}$ type of bonding is as versatile as in the case of the $\eta^{3}$. allyl compounds. An example of a rather extreme case is $\left(\eta^{5}-\mathrm{C}_{5} \mathrm{H}_{5}\right) \mathrm{MoI}(\mathrm{CO})\left\{\mathrm{C}\left(\mathrm{NMe}_{2}\right) \mathrm{C}(\mathrm{Me}) \mathrm{N}(\mathrm{Me})\right\}$, the bonding of which is described as a carbene with an adjacent $\eta^{2}-\mathrm{C}=\mathrm{N}$ bond to Mo [45]. This is also apparent from the different $\mathrm{C}-\mathrm{C}$ and $\mathrm{N}-\mathrm{C}$ bond lengths of $1.33 \AA$ and $1.46 \AA$, respectively [47].

Infrared measurements show the presence of a hydrogen atom bonded to one $\mathrm{N}$-atom of the R-DAB group $\left(\nu_{\mathrm{N}-\mathrm{H}} 3290 \mathrm{~cm}^{-1}\right)$. This was confirmed by carrying out the reaction with [DFe$\left.(\mathrm{CO})_{4}\right]^{-}$. The $\nu_{\mathrm{N}-\mathrm{D}}$ stretching mode arises at $2430 \mathrm{~cm}^{-1}$, while the signal at $3290 \mathrm{~cm}^{-1}$ is absent. It appears therefore that during the reaction of $\left[\mathrm{HFe}(\mathrm{CO})_{4}\right]^{-}$with $\mathrm{MnBr}(\mathrm{CO})_{3}(\mathrm{R}-\mathrm{DAB})$ the hydrogen atom has been transferred to a $\mathrm{N}$-atom of the dimine ligand [46].

In the first step of the reaction (Scheme 3) $\mathrm{Br}^{-}$ is replaced by $\left[\mathrm{HFe}(\mathrm{CO})_{4}\right]^{-}$. The second step may involve a double bond insertion of one $\mathrm{C}=\mathrm{N}$ unit 


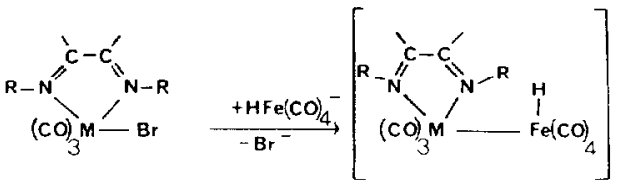

$$
\begin{aligned}
& \downarrow
\end{aligned}
$$

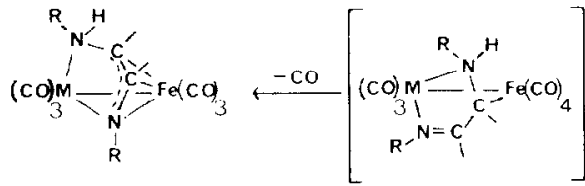

Scheme 3. Possible reaction pathway for the formation of $\mathrm{FeM}(\mathrm{CO})_{6}(\mathrm{R}-\mathrm{AAA})(\mathrm{M}=\mathrm{Mn}, \mathrm{Re})$.

into the $\mathrm{Fe}-\mathrm{H}$ bond, after which one $\mathrm{CO}$ group dissociates and the $\eta^{3}$-azaallyl compound is formed (Scheme 3). Another alternative involves a S.E.T. (Single Electron Transfer) reaction occurring within the molecule (Scheme 4). Migration of the H-atom within the radical pair may then result in $\mathrm{N}-\mathrm{H}$ bond formation, since in the $\left[\mathrm{M}(\mathrm{CO})_{3}(\mathrm{R}-\mathrm{DAB})\right]^{\circ}$ radical the spin density on the $\mathrm{N}$-atom is probably higher than that on the imine C-atoms. A final alternative, following the substitution step, might

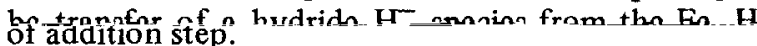

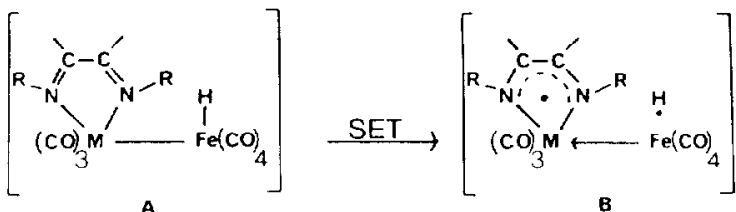<smiles>C1CCCC1</smiles>

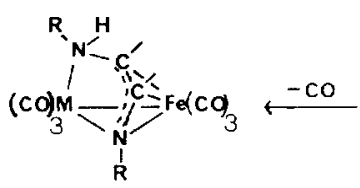

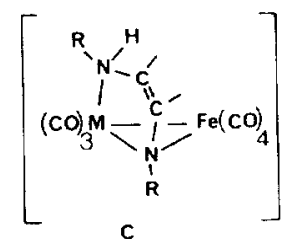

Scheme 4. Possible reaction pathway for the formation of FeM(CO) ${ }_{6}$ (R-AAA) involving S.E.T.

In all three alternatives $\mathrm{CO}$ elimination takes place after $\mathrm{H}$-migration from $\mathrm{Fe}$ to ligand. This agrees with the finding that $\mathrm{Fe} \operatorname{Re}(\mathrm{CO})_{6}(\mathrm{i}-\mathrm{Pr}-\mathrm{AAA})$ when heated yielded the isomeric hydride $(\mu$ $\mathrm{H}) \mathrm{Fe} \operatorname{Re}(\mathrm{CO})_{6}(\mathrm{i}-\mathrm{Pr}-\mathrm{DAB})$ in a first order reaction [48]. The standard energy of activation $\Delta G^{*}=$ $27 \mathrm{kcal} / \mathrm{mol}$. It may therefore be concluded that the hydride compound is thermodynamically more stable than the azaallylic complex [48].

Further information was obtained by studying the reactions of $\left[\mathrm{HFe}(\mathrm{CO})_{4}\right]^{-}$with $\operatorname{MBr}(\mathrm{CO})_{3}(\alpha-$ diimine $)(\mathrm{M}=\mathrm{Mn}, \alpha$-diimine $=\mathrm{R}$-Pyca with $\mathrm{R}=$ $\mathrm{i}-\mathrm{Pr}, \quad \mathrm{t}-\mathrm{Bu} ; \quad \mathrm{M}=\mathrm{Re}, \quad \alpha$-diimine $=\mathrm{i}-\mathrm{Pr}$-Pyca or $\mathrm{R}$ DAB with $R=i-P r, c-H e x$, or i-Pr-DAB $\left\{\mathbf{H} ; \mathrm{CH}_{3}\right\}$ at $40^{\circ} \mathrm{C}$ in THF. For these combinations of metals and ligands the hydride complexes $(\mu-\mathrm{H}) \mathrm{FeM}(\mathrm{CO})_{6}$ ( $\alpha$-diimine) $(\mathrm{M}=\mathrm{Mn}, \mathrm{Re})$ were isolated [48]. The crystal structure determination of $(\mu-\mathrm{H}) \mathrm{FeMn}(\mathrm{CO})_{6}$ (t-Bu-Pyca) (Fig. 17) showed a FeMn bond of 2.7465(3) $\AA$ bridged by a H-atom involving an

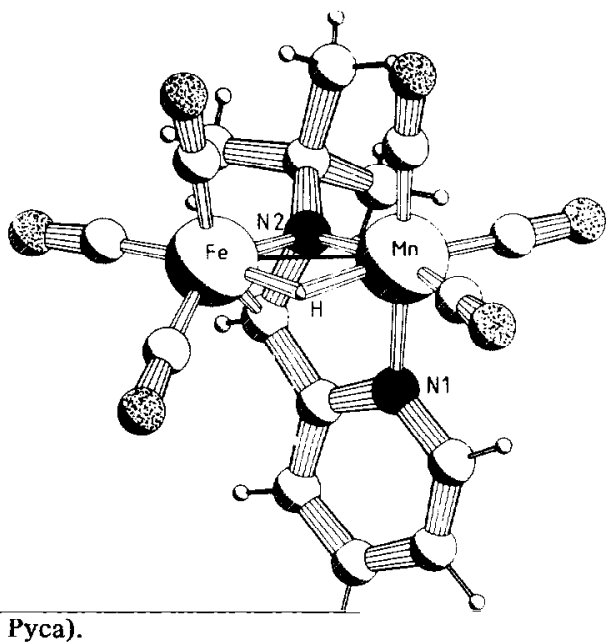

asymmetrically bent $\mathrm{Fe}-\mathrm{H}-\mathrm{Mn}$ interaction. The $\mathrm{Fe}-\mathrm{H}$ bond distance is $1.61(2) \AA$ and the $\mathrm{Mn}-\mathrm{H}$ bond distance is $1.73(2) \AA$. There are three terminal $\mathrm{CO}$ groups on each metal atom (Fig. 17). The R-Pyca is $\sigma$-N bonded via the pyridyl $\mathrm{N}$-atom to $\mathrm{Mn}$ and $\eta^{2}-\mathrm{C}=\mathrm{N}$ bonded via the imine bond to $\mathrm{Fe}$. The imine $\mathrm{N}=\mathrm{C}$ bond distance is $1.408(2)$ $\AA$, as expected for a $\eta^{2}$-bonded unit. The central C-C bond of the R-DAB of 1.464(2) $A$ is normal for a single $\mathrm{C}\left(\mathrm{sp}^{2}\right)-\mathrm{C}\left(\mathrm{sp}^{2}\right)$ bond. The $\eta^{2}$ bonding of the imine group is further reflected by the ${ }^{1} \mathrm{H}$ NMR chemical shift of about $4 \mathrm{ppm}$ for the imine $\mathrm{H}$-atom. The metal-metal bridging $\mathrm{H}$-atom gives one singlet at $-16 \mathrm{ppm}$, as expected for this type of bonding. There is no evidence for $\mathrm{CO}$ scrambling in the molecule in solution between -40 and $+35^{\circ} \mathrm{C}$.

It is clear from the previous observations that the course of the reaction of $\left[\mathrm{HFe}(\mathrm{CO})_{4}\right]^{-}$with $\mathrm{MBr}(\mathrm{CO})_{3}(\mathrm{R}-\mathrm{DAB})$ is very sensitive with regard to the choice of metals and ligands. Naturally in the case of R-Pyca the $\eta^{3}$-azaallylic type of bonding is not possible, since this would require loss of resonance stabilization in the pyridine ring.

In general one may expect as the first step a substitution of $\mathrm{Br}^{-}$by $\left[\mathrm{HFe}(\mathrm{CO})_{4}\right]^{-}$. Thereafter two routes are possible. Firstly, a $\mathrm{CO}$ elimination from $\mathrm{Fe}$ takes place with subsequent $\eta^{2}$-coordination 
of one $\mathrm{C}=\mathrm{N}$ bond of the diimine ligand into the vacated position on $\mathrm{Fe}$. After a small movement of the $\mathrm{H}$-atom to an asymmetric bridging position the final hydride product is obtained. In the case of the R-DAB ligands this route is a possibility, but another one is also feasible. This would involve a $\mathrm{C}=\mathrm{N}$ insertion into the $\mathrm{Fe}-\mathrm{H}$ bond to be followed by $\mathrm{CO}$ elimination from $\mathrm{Fe}$ and $\eta^{2}$-coordination of the second $\mathrm{C}=\mathrm{N}$ moiety to $\mathrm{Fe}$. The neutral R-DAB is changed into a mono-anionic 3-amino-1-azaallyl ligand. This step is not possible for R-Pyca, as mentioned before. The resulting $\eta^{3}$-azaallylic product is stable for $M=M n$ and $\alpha$-diimine equals R-DAB, but for $M=\operatorname{Re}$ the reaction may continue to give the hydride $(\mu-\mathrm{H}) \mathrm{Fe} \operatorname{Re}(\mathrm{CO})_{6}(\mathrm{R}-\mathrm{DAB})$. This step may be a deinsertion reaction, whereby the $\mathrm{H}$-atom migrates back from the $\mathrm{N}$-atom to the metal pair $[46,48]$.

When one uses a nonsymmetric R-DAB ligand, i.e. $\quad \mathrm{i}-\mathrm{PrN}=\mathrm{C}(\mathrm{H})(\mathrm{Me}) \mathrm{C}=\mathrm{N}-\mathrm{i}-\mathrm{Pr} \quad$ (i-Pr-DAB $\{\mathrm{H} ; \mathrm{Me}\})$ two isomers may be expected when $\operatorname{MnBr}(\mathrm{CO})_{3}$ (i-Pr-DAB $\{\mathrm{H} ; \mathrm{Me}\})$ is treated with $\left[\mathrm{HFe}(\mathrm{CO})_{4}\right]^{-}$. This is indeed the case since both Fe $\overline{\mathrm{Mn}\{(\mathrm{i} \cdot \mathrm{Pr}) \overline{\mathrm{N}} \overline{\mathrm{C}}}$ $\overline{(\mathrm{H}) \bar{C}(\mathrm{Me}) \mathrm{N}}(\mathrm{H})(\mathrm{i}-\mathrm{Pr})\}$ and $\mathrm{Fe} \overline{\mathrm{Mn}\{(\mathrm{i}-\mathrm{Pr} \overline{\mathrm{N}} \overline{\mathrm{C}}(\overline{\mathrm{Me}}) \overline{\mathrm{C}}(\mathrm{H}) \mathrm{N}}$ (H)(i-Pr) $\}$ are obtained in unequal ratio [48]. However, reaction of $\operatorname{Re}(\mathrm{CO})_{3}(\mathrm{i}-\mathrm{Pr}-\mathrm{DAB}\{\mathrm{H} ; \mathrm{Me}\})$ with $\left[\mathrm{HFe}(\mathrm{CO})_{4}\right]^{-}$afforded only one isomer, i.e. $(\mu-\mathrm{H}) \mathrm{Fe} \operatorname{Re}(\mathrm{CO})_{6}(\mathrm{i}-\mathrm{Pr}-\mathrm{DAB}\{\mathrm{H} ; \mathrm{Me}\})$ with the $\mathrm{C}(\mathrm{H})=\mathrm{N}$ part of the R-DAB ligand $\eta^{2}$-bonded to Fe. This implies that if the last reaction takes place via the first mentioned route then only the $\mathrm{C}(\mathrm{H})=\mathrm{N}$ bond will become $\eta^{2}$-bonded to $\mathrm{Fe}$ after loss of $\mathrm{CO}$. If the second route is utilized, i.e. via the 3-amino-1azaallylic intermediate, then one would expect also both possible isomers of $(\mu-\mathrm{H}) \mathrm{Fe} \operatorname{Re}(\mathrm{CO})_{6}$ (i-PI$\mathrm{DAB}\{\mathrm{H} ; \mathrm{Me}\})$. As a consequence the last step, i.e. replacement of $\eta^{2}$-coordination of the $C(\mathrm{Me})=\mathrm{N}$ moiety to that of the $\mathrm{C}(\mathrm{H})=\mathrm{N}$ part, must be rapid [48].

A surprising finding was that reaction of $\mathrm{MnBr}$ $(\mathrm{CO})_{3}$ (p-Tol-DAB) with excess $\left[\mathrm{HFe}(\mathrm{CO})_{4}\right]^{-}$and subsequent protonation gave $(\mu-\mathrm{H}) \mathrm{FeMn}\left(\mu, \mu^{\prime}\right.$-p-Tol$\mathrm{NCH}_{2} \mathrm{CH}_{2} \mathrm{~N}$-p-Tol), which shows that during the reaction the chelating 4e-R-DAB donor is reduced to the formally dianionic 8e-bonded 1,2-di-p-tolylaminoethane group [49]. The crystal structure determination of this compound showed that the molecule contains a very short $\mathrm{MnFe}$ bond (2.5393(9) $\AA$ ) bridged by a H-atom with $\mathrm{Mn}-\mathrm{H}$ and $\mathrm{Fe}-\mathrm{H}$ bond distances of $1.70(6) \AA$ and $1.83(6) \AA$, respectively (Fig. 18). All eighteen atoms of the (p-Tol) $\mathrm{NCH}_{2} \mathrm{CH}_{2} \mathrm{~N}(\mathrm{p}$-Tol) skeleton are in one plane, perpendicular to the $\mathrm{Fe}-\mathrm{H}-\mathrm{Mn}$ plane. There are six terminal $\mathrm{CO}$ groups with three $\mathrm{CO}$ ligands per metal atom. ${ }^{1} \mathrm{H}$ and ${ }^{13} \mathrm{C}$ NMR data indicate a similar structure in solution with the bridging hydride atom resonating at $-10.02 \mathrm{ppm}$, relatively

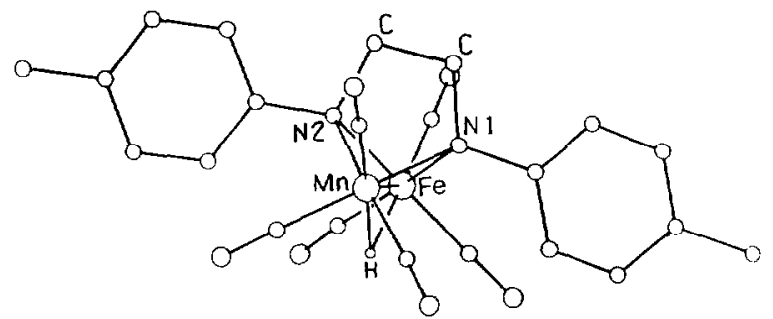

Fig. 18. Molecular geometry of $\left\{(\mu-\mathrm{H}) \mathrm{FeMn}(\mathrm{CO})_{6}\left\{\mu, \mu^{\prime}-\right.\right.$ $\left.\mathrm{N}(\mathrm{p}-\mathrm{Tol}) \mathrm{CH}_{2} \mathrm{CH}_{2} \mathrm{~N}(\mathrm{p}-\mathrm{Tol})\right\}$.

low for a bridging hydride. The three $\mathrm{CO}$ groups on the $\mathrm{Fe}$ atom are rapidly interchanging on the NMR time scale at $-40{ }^{\circ} \mathrm{C}$ [49].

When $\operatorname{MnBr}(\mathrm{CO})_{3}$ (p-Tol-DAB) is reacted with excess of $\left[\mathrm{DFe}(\mathrm{CO})_{4}\right]^{-}$then the hydride $(\mu-\mathrm{H})$ FeMn(CO) ${ }_{6}\left\{\mu, \mu^{\prime}\right.$-p-TolNC(H)DCH(D)N(p-Tol $\}$ is obtained after protonation, as was evidenced by ${ }^{1} \mathrm{H}$ NMR. The proposed reaction path is shown in Scheme 5.
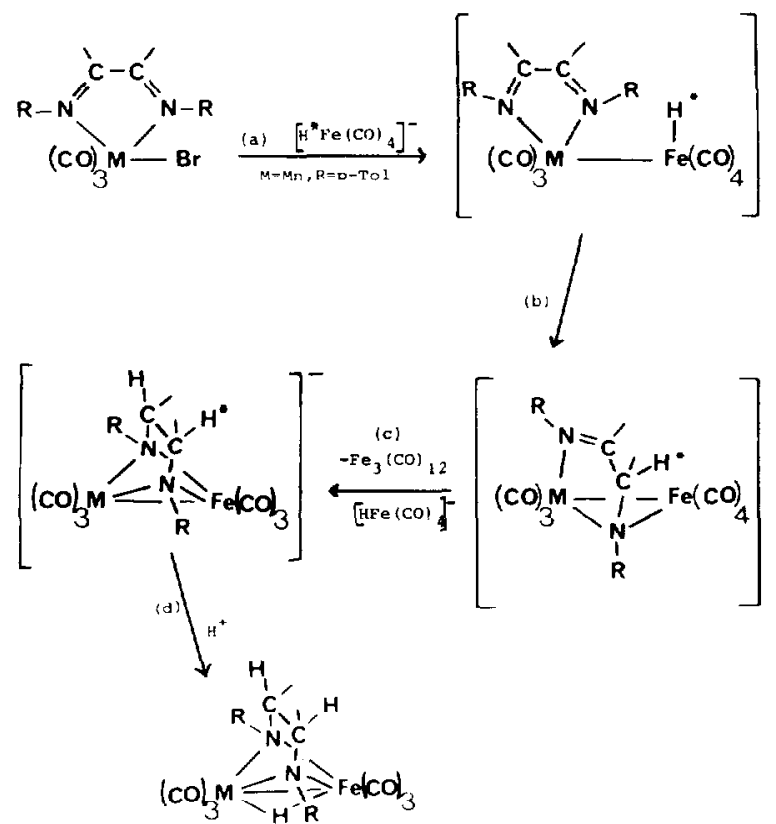

Scheme 5. Possible reaction route for the formation of ( $\mu$ $\mathrm{H}) \mathrm{FeM}(\mathrm{CO})_{6}\left\{\mu, \mu^{\prime}-\mathrm{N}(\mathrm{p}-\mathrm{Tol}) \mathrm{CH}_{2} \mathrm{CH}_{2} \mathrm{~N}-\mathrm{p}-\mathrm{Tol}\right\}$.

The first step involves a substitution of $\mathrm{Br}^{-}$by $\left[\mathrm{HFe}(\mathrm{CO})_{4}\right]^{-}$, while the second step may be an insertion of one $\mathrm{C}=\mathrm{N}$ bond into the $\mathrm{Fe}-\mathrm{H}$ bond, resulting in $\mathrm{C}-\mathrm{H}$ bond formation which takes place with a cis-stereospecificity. This is normally found for reactions of metal hydrides with unsaturated compounds. Step (b) may involve a hydride transfer from the $\mathrm{Fe}$ to the positively polarized $\mathrm{C}$-atom. Another reaction route following the primary substitution mentioned above is a SET reaction producing a $\left[\mathrm{Mn}(\mathrm{CO})_{3} \text { (p-Tol-DAB) }\right]^{\circ}$ and a $^{\circ}$ radical. Subsequently $\mathrm{C}-\mathrm{H}$ bond formation occurs, because the spin density in the $\left[\mathrm{Mn}(\mathrm{CO})_{3}\right.$ (p-Tol- 
DAB) $]^{\circ}$ radical would be highest on the imine $C$ atom, as spin density on the imine $\mathrm{N}$-atom would be reduced owing to delocalization on the aryl rings. Thirdly a concerted mechanism may be involved.

These reactions closely resemble the situation found for the organo- $\mathrm{Zn}$ and organo-Al R-DAB compounds, where one also obtains $\mathrm{C}$ - and N-alkylation, depending on a variety of factors.

In the third step (c) the remaining $\mathrm{C}=\mathrm{N}$ bond is reduced by $\left[\mathrm{HFe}(\mathrm{CO})_{4}\right]^{-}$. Because of bond polarization and steric factors the reducing [HFe$\left.(\mathrm{CO})_{4}\right]^{-}$anion will approach the imine bond in such a fashion that the second new $\mathrm{C}-\mathrm{H}$ bond will be in a trans position with respect to the first one. Finally, coordination of the $\mathrm{N}$-atom to $\mathrm{Fe}$ with concomitant loss of $\mathrm{CO}$ followed by protonation with dilute acid or silica gives the final product (step d) with some $\mathrm{Fe}_{3}(\mathrm{CO})_{12}$ being formed from iron carbonyl fragments in the second reduction by $\left[\mathrm{HFe}(\mathrm{CO})_{4}\right]^{-}$ (Scheme 5, step c).

It may be concluded that the seemingly simple substitution reaction of $\mathrm{MBr}(\mathrm{CO})_{3}$ ( $\alpha$-diimine) $(\mathrm{M}=$ $\mathrm{Mn}, \mathrm{Re})$ with $\left[\mathrm{HFe}(\mathrm{CO})_{4}\right]^{-}$may lead to three reaction products A, B or C (Fig. 19).

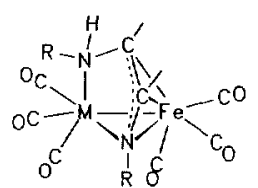

A

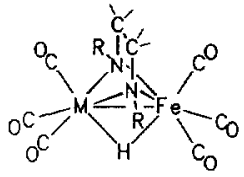

B

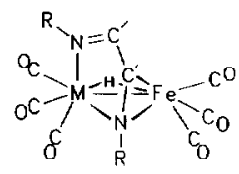

C

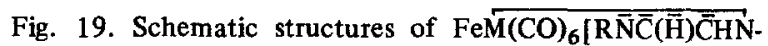
(H)R] (A), $(\mu-\mathrm{H}) \mathrm{FeM}(\mathrm{CO})_{6}\left(\mathrm{RNCH}_{2} \mathrm{CH}_{2} \mathrm{NR}\right)(\mathrm{B})$, and $(\mu$ $\mathrm{H}) \mathrm{FeM}(\mathrm{CO})_{6}(\mathrm{R}-\mathrm{DAB})(\mathrm{C})(\mathrm{M}=\mathrm{Mn}, \mathrm{Re})$.

For $\mathbf{M}=\mathbf{M n}$ and $\alpha$-diimine is $\mathrm{R}-\mathrm{DAB}$ with $\mathrm{R}$ is alkyl product $A$ is obtained. For $M=R e$ and $R$ is alkyl product $\mathbf{C}$ is isolated, probably produced via $\mathbf{A}$ as an intermediate. Finally, when $M=M n$ and $R$ is p-Tol and using excess $\left[\mathrm{HFe}(\mathrm{CO})_{4}\right]^{-}, \mathrm{C}$ is the main product, because of delocalization effects of the p-Tol groups. In this reaction traces of $\mathbf{A}$ and $\mathbf{B}$ have been observed (less than $5 \%$ ).

\section{H. Reactions of $R_{2} Z n$ and $R_{3} A l$ with $R-D A B$ and R-Pyca}

In the previous sections it has been shown that the R-DAB ligand and also, although to a lesser extent, the R-Pyca ligand are both versatile with regard to their coordination properties and to their chemical reactivity. With respect to the chemical reactivity a host of reactions was discovered, i.e. $\mathrm{C}-\mathrm{C}, \mathrm{C}-\mathrm{H}, \mathrm{N}-\mathrm{C}$ and $\mathrm{N}-\mathrm{H}$ bond formation involving the $\alpha$-diimine and an added substrate.
Obviously such chemical versatility could also have a large potential for reactions of $\alpha$-dimines with, e.g. organomagnesium, organozinc and organoaluminium reagents. Although the subject has not yet been studied in great depth some very interesting results have emerged $[31,35]$.

An illustration of the type of chemistry that has been discovered is shown in scheme 6 , where a survey is given of the reactions of $\mathrm{ZnFt}_{2}$ with R-DAB and R-Pyca $(R=t-B u)$.

It has now been established that $\mathrm{ZnEt}_{2}$ with $\alpha$-diimine gives $\mathrm{ZnEt}_{2}$ ( $\alpha$-diimine) with the $\alpha$ diimine acting as a $4 \mathrm{e} \sigma, \sigma-\mathrm{N}, \mathrm{N}^{\prime}$ donor ligand. Depending on whether t-Bu-DAB or t-Bu-Pyca are used two major routes appear to be likely [31]. In the case of $t-B u-D A B$ the $\mathrm{N}$-alkylated product $\mathrm{ZnEt}\{\mathrm{t}-\mathrm{Bu}-\mathrm{NC}(\mathrm{H})=\mathrm{C}(\mathrm{H}) \mathrm{N}(\mathrm{Et})-\mathrm{t}-\mathrm{Bu}\}$ is formed in almost quantitative yields. It was proposed that the reaction proceeds by a SET reaction which produces $Z n E t\{t-B u-N C(H)=C(H) N(E t)-t-B u\}$ by a 1,2 shift of $E t$ via a radical pair $[\mathrm{EtZn}(\mathrm{t}-\mathrm{Bu}$ DAB) $\left.{ }^{\circ} t^{\circ}\right]$ as transition state. If in a side reaction the ethyl radical escapes then the radical [EtZn(tBu-DAB) $]^{*}$ is formed which, as discussed before, can dimerise to $\mathrm{Zn}_{2} \mathrm{Et}_{2}$ (IAE) [35]. A quantitative route to this compound involves the reaction of $[\mathrm{EtZnCl}]_{2}$ with $\mathrm{K}[\mathrm{t}-\mathrm{Bu}-\mathrm{DAB}]$. No C-alkylated product is formed, in accord with the higher spin density on the $\mathrm{N}$-atoms, as derived by ESR on the radical [EtZn(t-Bu-DAB) $]^{\bullet}$ [35] (vide infra).

In the case of $\mathrm{ZnEt}_{2}(\mathrm{t}-\mathrm{Bu}-\mathrm{Pyca})$ the $\mathrm{N}$-alkylation route is not possible since this would result in the break-up of the conjugation in the pyridyl ring. An alternative route, which may proceed via a zinc hydride intermediate or transition state $\mathbf{B}$ or B' (Scheme 6), now becomes viable. The participation of ethyl radicals could be ruled out since $75 \%$ of one Et group was formed back as a 1/1 molar mixture of ethylene and ethane without any trace of butane. The species $\mathbf{B}$ or $\mathbf{B}^{\prime}$ could be formed via $\beta$-elimination or via a transition state $\mathbf{A}$. Subsequently ethylene would be eliminated from the ethyl radical in $\mathbf{A}$ and the $\left[\mathrm{EtZn}(\mathrm{t}-\mathrm{Bu}-\mathrm{Pyca})^{\mathrm{H}^{*}}\right.$ radical pair $\mathbf{B}$ or $\mathbf{B}^{\prime}$ would be formed. The formation of $\mathbf{A}$ is not improbable since a $\mathbf{C}$-alkylated product was formed in the case of the reaction with t-Bu-Pyca, i.e. $\mathrm{EtZn}\left\{\mathrm{C}_{5} \mathrm{H}_{4} \mathrm{NCH}(\mathrm{Et}) \mathrm{N}-\mathrm{t}-\mathrm{Bu}\right\}$.

The species $B$ (or $\mathbf{B}^{\prime}$ as a result of a $S E T$ reaction) may now lead to the reduced compound $\mathrm{ZnEt}\left(\mathrm{C}_{5}-\right.$ $\mathrm{H}_{4} \mathrm{NCH}_{2} \mathrm{~N}$-t-Bu) or react with unreacted $\mathrm{ZnEt}_{2}(\mathrm{t}$ $\mathrm{Bu}-\mathrm{Pyca})$ to afford the radical [ZnEt(t-Bu-Pyca) ${ }^{\circ}$ and an equivalent of ethane.

Further indications for the formation of the species $\mathbf{B}$ (or $\mathbf{B}^{\prime}$ ) originate from the finding that a $1 / 1$ reaction of $\mathrm{Zn}(\mathrm{H}) \mathrm{Et} \cdot$ pyridine with $\mathrm{t}$-Bu-Pyca yielded quantitatively the reduced product $\mathrm{Zn}$ $\operatorname{Et}\left(\mathrm{C}_{5} \mathrm{H}_{4} \mathrm{NCH}_{2} \mathrm{~N}\right.$-t-Bu), while this same reaction, but now in the presence of 1 equivalent of $\mathrm{ZnEt}_{2}(\mathrm{t}-$ 


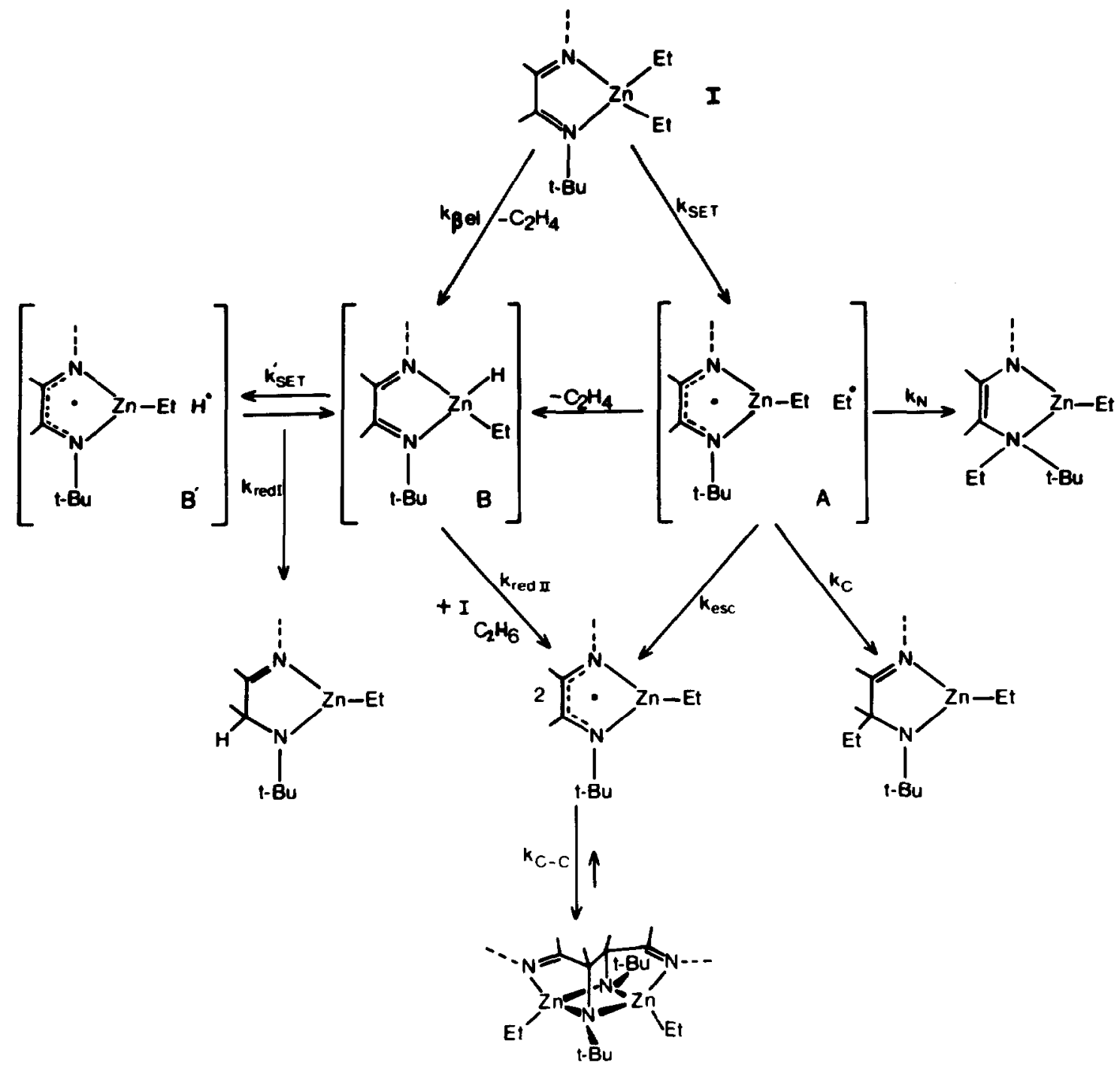

Scheme 6. Proposed reaction scheme of the reaction routes of initially formed $\mathrm{ZnEt}_{2}(\mathrm{t}-\mathrm{Bu}-\mathrm{DAB})$ and $\mathrm{ZnEt} \mathrm{t}_{2}$ (t-Bu-Pyca) to products.

Bu-Pyca), produced the reduced product, the $\mathrm{C}$ alkylated product $\mathrm{ZnEt}\left\{\mathrm{C}_{5} \mathrm{H}_{4} \mathrm{NC}(\mathrm{H})(\mathrm{Et}) \mathrm{N}-\mathrm{t}-\mathrm{Bu}\right\}$ and $\mathrm{Zn}_{2} \mathrm{Et}_{2}$ (IAE) (in equilibrium with [ $\mathrm{ZnEt}(\mathrm{t}-\mathrm{Bu}$ Pyca) $]^{\circ}$ ) in the same yields as observed for the reaction of t-Bu-Pyca with $\mathrm{ZnEt}_{2}$ [31]. However, in this case only ethane and not ethylene was formed as a product. Since the C-alkylated product was also formed it is likely that the radical pair A [ $\left.\mathrm{ZnEt}(\mathrm{t}-\mathrm{Bu}-\mathrm{Pyca})^{\circ} \mathrm{Et}{ }^{\circ}\right]$ was again produced.

Although we will not discuss in any detail the reaction of $\left[\mathrm{AlEt}_{3}\right]_{2}$ with $\mathrm{t}-\mathrm{Bu}-\mathrm{DAB}$ or $\mathrm{t}$-Bu-Pyca, it is relevent to mention some interesting differences. It appears that $\mathrm{t}$-Bu-DAB reacts with $\left[\mathrm{AlEt}_{3}\right]_{2}$ at $-40{ }^{\circ} \mathrm{C}$ to give $\mathrm{AlEt}_{3}$ (t-Bu-DAB) with the t-Bu-DAB ligand coordinated to the $\mathrm{AlEt}_{3}$ moiety in a monodentate fashion, while the ligand is in the s-trans configuration as deduced from ${ }^{1} \mathrm{H}$ NMR data. This type of coordination, probably via the imine bond, appears to occur also for t-Bu-Pyca in $\mathrm{AlEt}_{3}$ (t-Bu-Pyca) [31].

Further reaction of $\mathrm{AlEt}_{3}(\mathrm{t}-\mathrm{Bu}-\mathrm{DAB})$ produces not only $\mathrm{AlEt}_{2}\{\mathrm{t}-\mathrm{BuNC}(\mathrm{H})=\mathrm{C}(\mathrm{H}) \mathrm{N}(\mathrm{Et})(\mathrm{t}-\mathrm{Bu})\}$ (the $\mathrm{N}$-alkylated product) in $26 \%$ yield, but also the $\mathrm{C}$ alkylated products $\mathrm{AlEt}_{2}\left\{\mathrm{t}-\mathrm{BuN}=\mathrm{C}(\mathrm{Et}) \mathrm{C}(\mathrm{H}) \mathrm{CH}_{2} \mathrm{~N}\right.$ $\mathrm{t}$-Bu\} and $\mathrm{AlEt}_{2}\{\mathrm{t}-\mathrm{BuNC}(\mathrm{H})(\mathrm{Et}) \mathrm{C}(\mathrm{H})=\mathrm{N}-\mathrm{t}-\mathrm{Bu}\}$ in yields of $41 \%$ and $33 \%$ respectively [31]. Also some persistent radical [AlEt $\left.{ }_{2}(\mathrm{t}-\mathrm{Bu}-\mathrm{DAB})\right]^{\circ}(2 \%)$ was formed. However, further reaction of $\mathrm{AlEt}_{3}(\mathrm{t}-$ Bu-Pyca) only gave (98\% yield) the C-alkylated product AlEt ${ }_{2}\left\{2-\mathrm{C}_{5} \mathrm{H}_{4} \mathrm{NC}(\mathrm{H})(\mathrm{Et}) \mathrm{N}-\mathrm{t}-\mathrm{Bu}\right\}$ [31].

It seems not unlikely that for the case of $\mathrm{Al}$ a similar type of scheme can be drawn as for $\mathrm{Zn}$. The course of the reactions is however different, owing probably to the different coordination requirements 
of $\mathrm{Al}$ and to the fact that there are three Et groups present per $\mathrm{Al}$ atom thereby forcing the $\alpha$-diimine to a monodentate situation in initial stages of the reaction. This then gives rise to a reaction pattern different from that found for $\mathrm{Zn}$.

\section{Acknowledgements}

We thank Mr. J. Keijsper, Mr. L. H. Polm and Mr. J. T. B. H. Jastrzebski for their enthusiastic research efforts.

\section{References}

1 G. van Koten and K. Vrieze, Adv. Organomet. Chem., 21, 151 (1982).

2 G. van Koten and K. Vrieze, Recl. Trav. Chim. Pays Bas, 100,129 (1981).

3 V. Plank, J. Klaus, K. von Deuten, M. Feigel, H. Bruder and H. tom Dieck, Transition Met. Chem., 6, 185 (1981).

4 H. tom Dieck and W. Kollvitz, Transition Met. Chem., 7, 154 (1982).

5 H. tom Dieck, M. Svoboda and J. Kopf, Z. Naturforsch., Teil B:, 33, 1381 (1978).

6 R. W. Balk, T. Snoeck, D. J. Stufkens and A. Oskam, Inorg. Chem., 19, 3015 (1980).

7 H. W. Frühauf, J. Chem. Res. (S), 216 (1983); J. Chem. Res. (M), 2023 (1983).

8 R. Diercks and H. tom Dieck, Z. Naturforsch., Teil B:; 39, 180 (1984).

9 H. tom Dieck and J. Dietrich, Chem. Ber., 117, 694 (1984).

10 B. Crociani, T. Boschi and P. Uguagliati, Inorg. Chim. Acta, 48, 9 (1981).

11 J. Reinhold, R. Benedix, P. Birner and H. Hennig, Inorg. Chim. Acta, 33, 209 (1979).

12 R. D. Adams, J. Am. Chem. Soc, 102, 7476 (1980)

13 D. Walter and M. Teutsch, Z. Chem., 16, 118 (1976).

14 J. Keijsper, H. van der Poel, L. H. Polm, G. van Koten and $\mathrm{K}$. Vrieze, Polyhedron, 2, 1111 (1983).

15 H. van der Poel, G. van Koten, K. Vrieze, M. Kokkes and C. H. Stam, Inorg. Chim. Acta, 39, 197 (1980).

16 J. Keijsper, L. H. Polm, G. van Koten, K. Vrieze, G. Abbel and C. H. Stam, Inorg. Chem., 23, 2142 (1984).

17 J. Keijsper, L. H. Polm, G. van Koten, K. Vrieze, F. A. B. Seignette and C. H. Stam, Inorg. Chem., (1985) in press.

18 M. W. Kokkes, D. J. Stufkens and A. Oskam, J. Chem. Soc., Dalton Trans., 439 (1983).

19 H. W. Frühauf, A. Landers, R. Goddard and C. Krüger, Angew. Chem., 90, 56 (1978).

20 L. H. Staal, L. H. Polm, R. W. Balk, G. van Koten, K. Vrieze and A. M. F. Brouwers, Inorg. Chem., 19, 3343 (1980).
21 L. H. Staal, J. Keijsper, L. H. Polm and K. Vrieze, J. Organomet. Chem., 204, 101 (1981).

22 L. H. Staal, G. van Koten and K. Vrieze, J. Organomet. Chem., 206, 99 (1981).

23 L. H. Staal, L. H. Polm, K. Vrieze, F. Ploeger and C. H. Stam, Inorg. Chem., 20, 3590 (1981).

24 J. Keijsper, G. van Koten, K. Vrieze, M. Zoutberg and C. H. Stam, (1985), to be published.

25 J. Keijsper, L. H. Polm, G. van Koten, K. Vrieze, K. Goubitz and C. H. Stam, Organometallics, (1985), in press.

26 W. A. Herrmann, Adv. Organomet. Chem., 20, 159 (1982).

27 J. C. Lui, J. C. V. Calabrese and S. S. Wreford, J. Am. Chem. Soc., 105, 1679 (1983).

28 J. Keijsper, L. H. Polm, G. van Koten, K. Vrieze, E. Nielsen and C. H. Stam, Organometallics, (1985), in press.

29 G. J. Kubas, R. R. Rijan, B. I. Swanson, P. J. Vergamin and H. J. Wasserman, J. Am. Chem. Soc., 106, 451 (1984).

30 L. H. Staal, A. Oskam, K. Vrieze, E. Roosendaal and H. Schenk, Inorg. Chem., 18, 1634 (1979).

31 G. van Koten, J. T. B. II. Jastrzebski and K. Vriczc, J. Organomet. Chem., 250, 49 (1983).

32 L. H. Polm, G. van Koten, K. Vrieze, B. F. K. van Santen and C. H. Stam, to be published.

33 L. H. Polm, G. van Koten, D. J. Stufkens, K. Vrieze, C. H. Stam and R. Andrea, to be published.

34 A. de Cian and R. Weiss, J. Chem. Soc., Chem. Commun., 249 (1976)

35 J. T. B. H. Jastrzebski, J. M. Klerks, G. van Koten and K. Vrieze, J. Organomet. Chem., 210, C49 (1981).

36 J. Keijsper, L. H. Polm, G. van Koten and K. Vrieze, Inorg. Chim. Acto, in press.

37 M. Pasquali, C. Floriani, A. Chiesi-Villa and C. Guastini, J. Am. Chem. Soc., 101, 4740 (1979)

38 M. Pasquali, S. Gambarotta, A. Floriani, A. Chiesi-Villa and C. Guastini, Inorg. Chem., 20, 165 (1981).

39 L. H. Staal, G. van Koten, K. Vrieze, B. van Santen and C. H. Stam, Inorg. Chem., 20, 3598 (1981).

$40 \mathrm{C}$. W. Bird, 'Transition Metal Intermediates in Organic Synthesis', Academic Press, New York, 1967.

41 W. Hübel and C. Hoogzand, Chem. Ber., 93, 103 (1960).

42 O. S. Mills and G. Robinson, Proc. Chem. Soc., London, 187 (1964).

43 I. H. Polm, G. van Koten, K. Vrieze, C. H. Stam and W. C. J. van Tunen, J. Chem. Soc., Chem. Commun. 1177 (1983).

44 L. H. Staal, G. van Koten and K. Vrieze, J. Organomet. Chem., 175, 73 (1979).

45 L. H. Staal, J. Keijsper, G. van Koten, K. Vrieze, J. A. Cras and W. P. Bosman, Inorg. Chem., 20, 555 (1981).

46 J. Keijsper, J. Mul, G. van Koten, K. Vrieze, H. C. Ubbels and C. H. Stam, Organometallics, 3, 1732 (1984).

47 R. D. Adams and D. F. Chodosk, J. Am. Chem. Soc., 99,6544 (1977).

48 J. Keijsper, P. Grimberg, G. van Koten, K. Vrieze, B. Kojić-Prodic and A. L. Spck, Organometallics, (1985), in press.

49 J. Keijsper, P. Grimberg, G. van Koten, K. Vrieze, M. Christophersen and C. H. Stam, Inorg. Chim. Acta, (1985), in press; J. T. B. H. Jastrzebski, G. van Koten and K. Vrieze, Inorg. Chim. Acta (1985) in press. 